\title{
Archaeological Survey for the Lower Greens Bayou Trail Project, Segments GR02 and GR03, in Harris County, Texas
}

Michael Quennoz

Jacob Hilton

Amanda Kleopfer

Tony Scott

Follow this and additional works at: https://scholarworks.sfasu.edu/ita

Part of the American Material Culture Commons, Archaeological Anthropology Commons, Environmental Studies Commons, Other American Studies Commons, Other Arts and Humanities Commons, Other History of Art, Architecture, and Archaeology Commons, and the United States History Commons

Tell us how this article helped you.

This Article is brought to you for free and open access by the Center for Regional Heritage Research at SFA ScholarWorks. It has been accepted for inclusion in Index of Texas Archaeology: Open Access Gray Literature from the Lone Star State by an authorized editor of SFA ScholarWorks. For more information, please contact cdsscholarworks@sfasu.edu. 


\section{Archaeological Survey for the Lower Greens Bayou Trail Project, Segments GR02}

and GR03, in Harris County, Texas

\section{Creative Commons License}

\section{(c) (1) (8)}

This work is licensed under a Creative Commons Attribution-NonCommercial 4.0 International License 


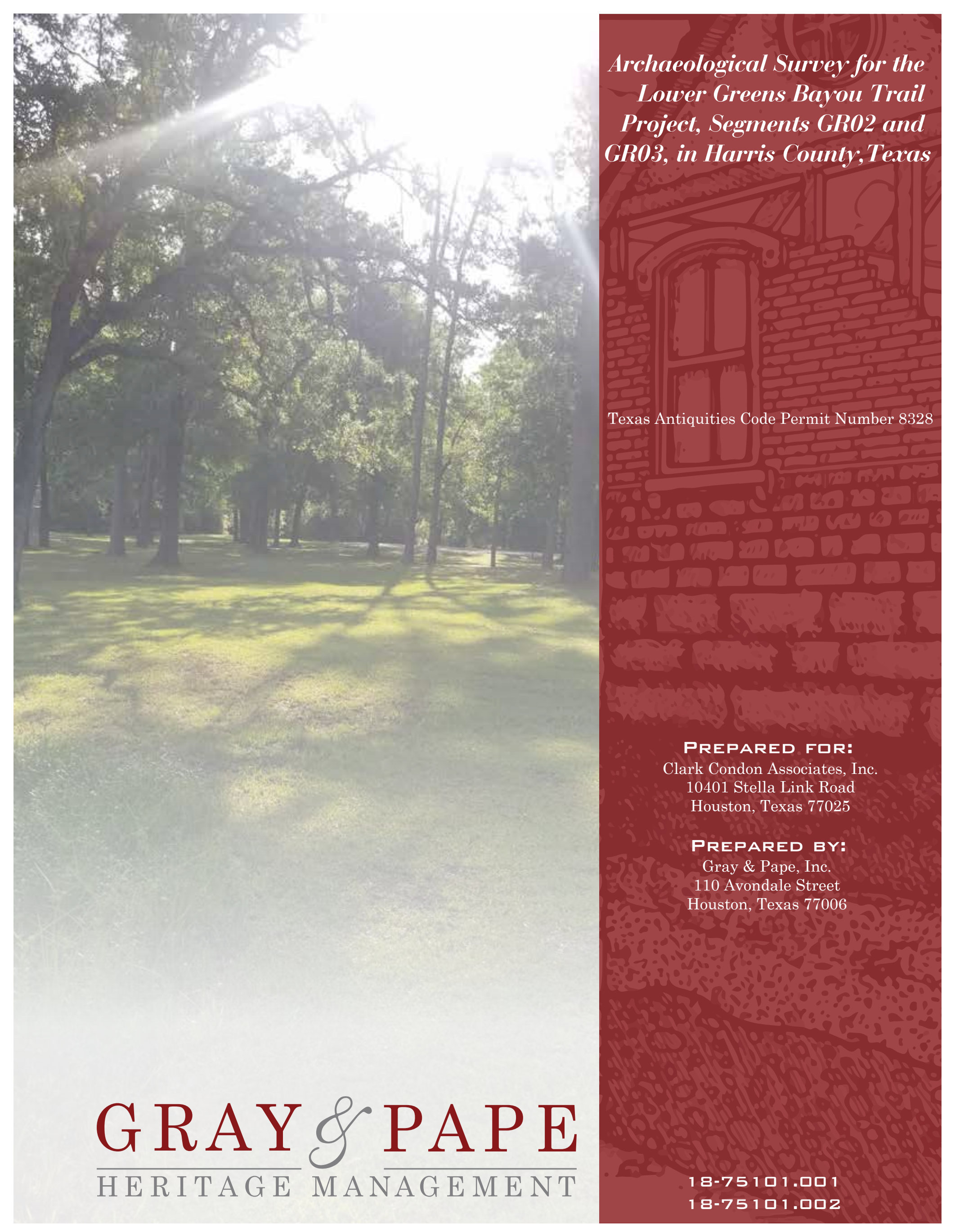




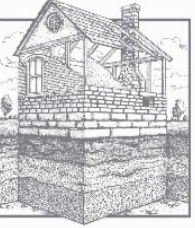

\section{GRAY $\&$ PAPE \\ HERITAGE MANAGEMENT}

Project No. 18-75101.001 and 18-75101.002

\section{Archaeological Survey for the Lower Greens Bayou Trail Project,} Segments GRO2 and GRO3, in Harris County, Texas

Texas Antiquities Permit No. 8328

Prepared for:

Clark Condon Associates, Inc.

10401 Stella Link Road

Houston, Texas 77025

Contact: Mary Keilers

(713) 871-1414

And

Houston Parks Board

Prepared by:

Michael Quennoz

Jacob Hilton

Amanda Kleopfer

And

Tony Scott

Gray \& Pape, Inc.

110 Avondale

Houston, Texas 77006

(713) 541-0473

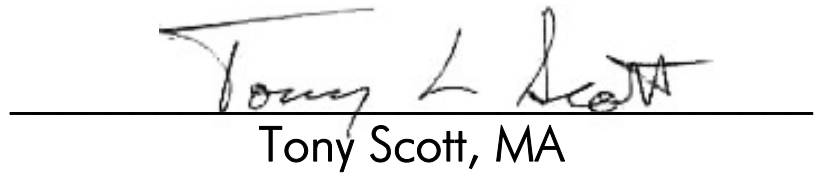

Sr. Principal Investigator

May 1, 2020 


\section{ABSTRACT}

Over several mobilizations between April 2018 and January 2020, Gray \& Pape, Inc., of Houston, Texas, conducted an intensive pedestrian cultural resources survey of two segments (Segments GR02 and GR03) of proposed trail development along Lower Greens Bayou in the City of Houston, Harris County, Texas. The project alignment measures approximately 10.8 kilometers $(6.7$ miles $)$ in length and encompasses approximately 9.6 hectares (23.7 acres) of area. Another 0.6 kilometers $(0.4$ miles $)$ or 0.6 hectares ( 1.4 acres) of project alignment was removed from consideration. In total, approximately 11.4 kilometers $(7.1$ miles) or 10.2 hectares $(25.1$ acres) was surveyed for the project. Because the proposed trail development occurs on publicly owned properties a Texas Antiquities Code Permit was required prior to survey. All work was completed under Texas Antiquities Permit \#8328, which was assigned by the Texas Historical Commission on February 14, 2018.

Fieldwork and reporting activities were performed according to procedures set forth by the Texas Historical Commission and the Council of Texas Archeologists. The goals of the survey were to establish whether or not previously unidentified archaeological resources were located within the project area, also defined as the project's Area of Potential Effects, and whether the proposed development would affect any previously identified cultural resources.

Prior to fieldwork, site file and background research was conducted, including a review of historic aerial and topographic maps in an attempt to locate any historic structures associated with the Area of Potential Effects. Site file review and background research indicated that there are no previously recorded sites within the project Area of Potential Effects.

Fieldwork took place between April 10, 2018 and January 7, 2020 and consisted of a combination of pedestrian survey and shovel testing. Systematic shovel testing was performed along a single transect over both project segments resulting in 131 shovel tests being excavated, of which 11 were positive for cultural material. The survey revealed that large portions of both project segments have been heavily disturbed by development and flood events, however, three new archaeological sites, 41HR1234, 41HR1235, and 41HR1236, and one historic Isolate were identified as a result of survey. Site 41 HR1234 was identified as a mid-twentieth century historic trash midden. Site 41HR1235 was identified as a Late Prehistoric ephemeral campsite. Site 41 HR 1236 was identified as a multicomponent prehistoric campsite and historic isolate. Diagnostic artifacts were observed at all three sites; however, it is the recommendation of Gray \& Pape, Inc. that only Sites 41HR1235 and 41HR1236 are significant in the materials they contain and their potential to offer additional research potential. Direct impacts to both sites have been avoided by the project alignment as currently planned. While indirect impacts such as looting are a concern, the distance between the sites and the current alignment as well the density of woods surrounding them minimizes the danger as a result of the project. Eligibility testing is recommended for the sites if they cannot be avoided by future projects.

Based on the results of this survey, Gray \& Pape, Inc. recommends that the no further cultural resources work be required for the project as currently planned and that the project be cleared to proceed. As specified under the conditions of Texas Antiquities Code Permit \#8328, all project associated records are curated with the Center of Archaeological Studies at Texas State University in San Marcos, Texas. 


\section{TABLE OF CONTENTS}

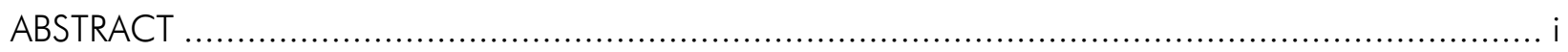

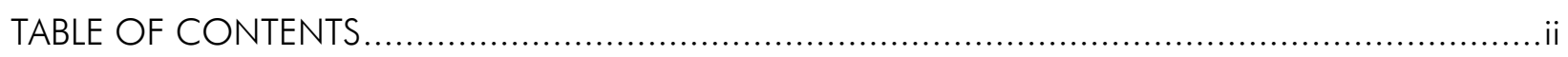

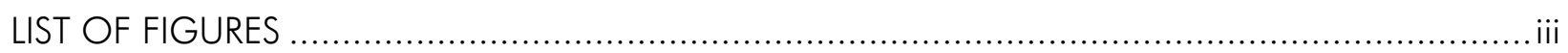

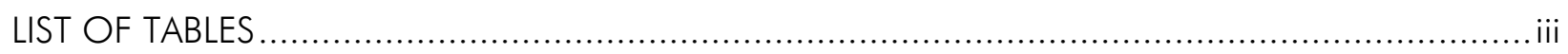

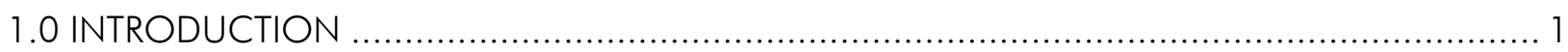

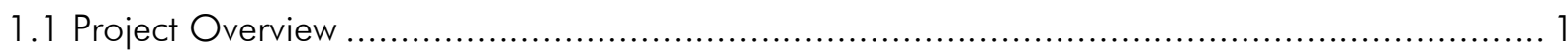

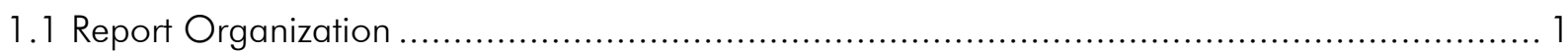

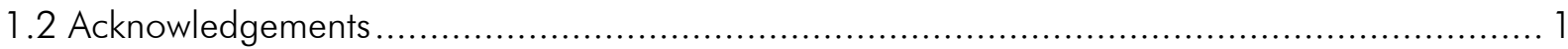

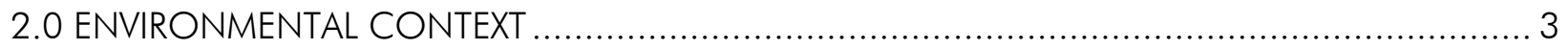

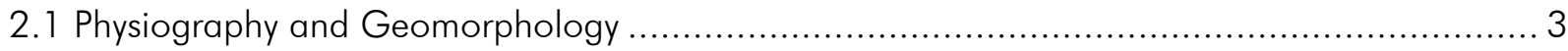

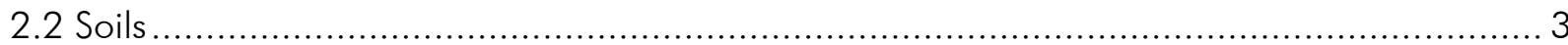

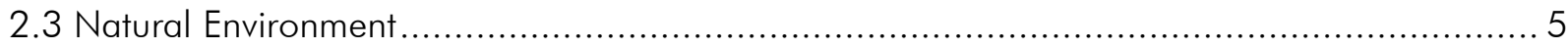

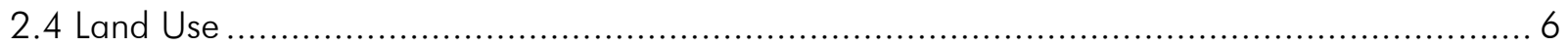

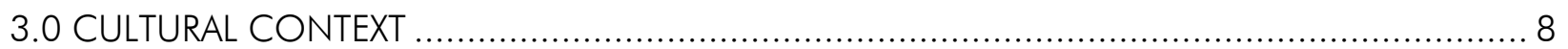

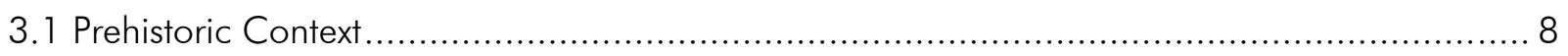

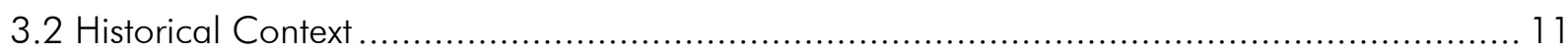

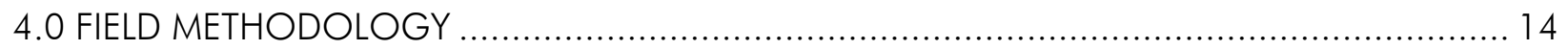

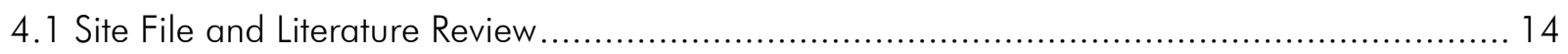

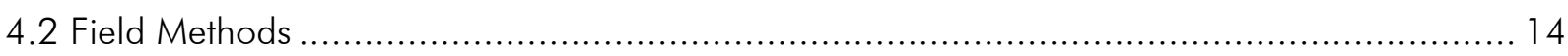

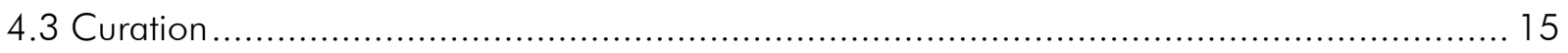

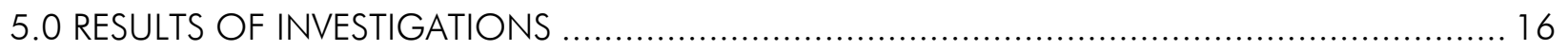

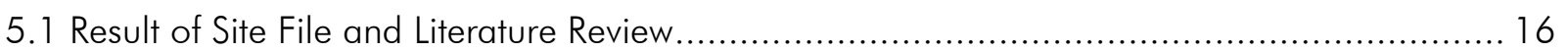

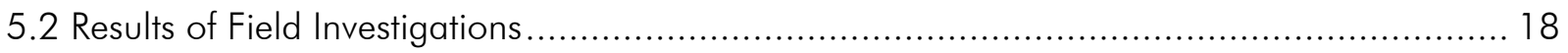

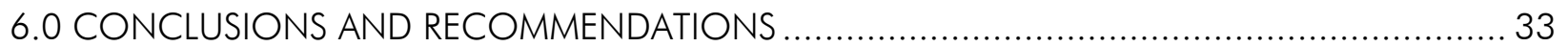

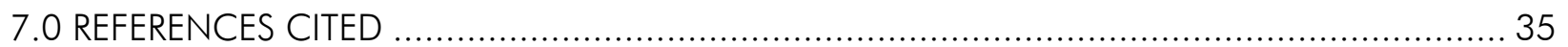

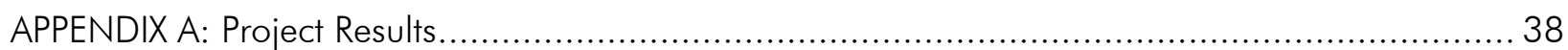

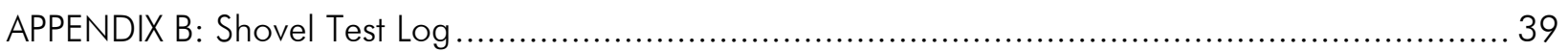




\section{LIST OF FIGURES}

Figure 1 1. Project area location in Harris County, Texas. ……............................................. 2

Figure 2-1. Project alignment overlaid on topographic maps circa 1916 (left) and 2018 (right). ....... 7

Figure 5-1. Current and former project alignment organized by Segment and Field showing newly

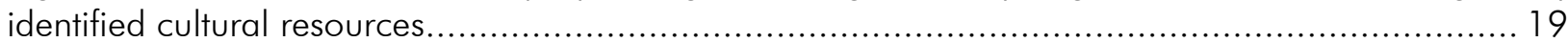

Figure 5-2. Current and former project alignment organized by Segment and Field showing newly

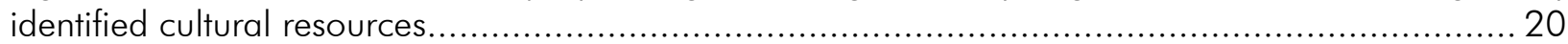

Figure 5-3. Portion of proposed trail located in Brock Park. View is to the west.......................... 22

Figure 5-4. Portion of proposed trail located adjacent to a landfill. Note the amount of refuse in the

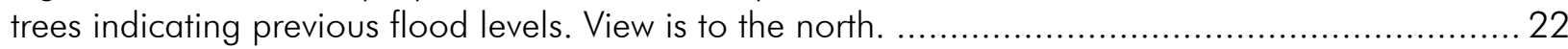
Figure 5-5. Portion of proposed trail located within an existing pipeline and transmission corridor. View

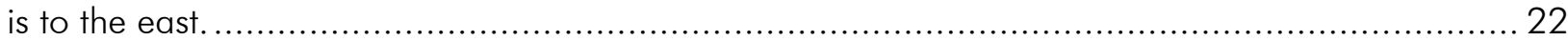

Figure 5-6. Portion of proposed trail located along a former cart path within the former Texaco Country

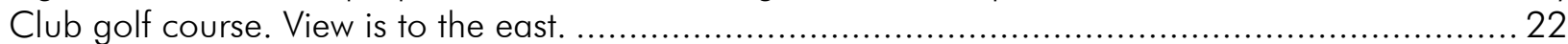

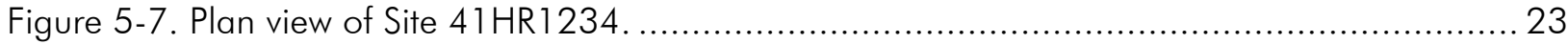

Figure 5-8. Burn pile of predominantly glass bottles observed within Site 41HR1234. View is to the east.

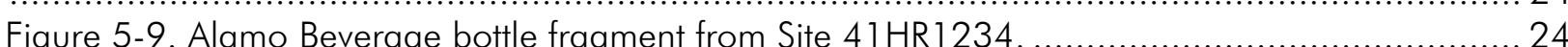

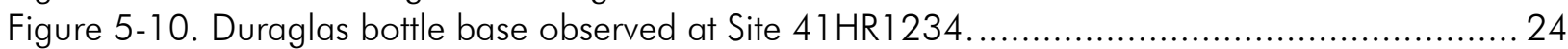

Figure 5-11. A "Grapette Products Co" bottle in the shape of a clown observed at Site 41 HR 1234. 24

Figure 5-12. Milk glass "MUM" deodorant jar observed at Site 41HR1234 ................................ 24

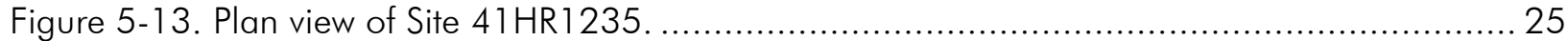

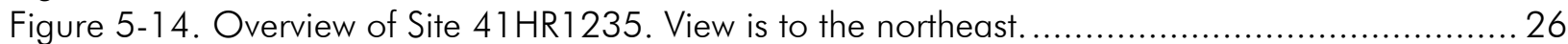

Figure 5-15. Representative artifacts observed at Site $41 \mathrm{HR} 1235$, including from left to right: ceramics, FCR, chert debitage, petrified wood debitage, and burned bone.............................................. 26

Figure 5-16. Overview of Site 41HR1236. View is to the southwest...................................... 27

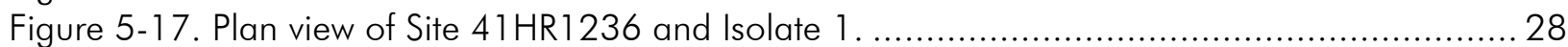

Figure 5-18. Representative prehistoric materials observed at Site 41HR1236 .........................2 29

Figure 5-19. Broken Perdiz arrow point observed at Site 41HR1 236 ....................................... 29

Figure 5-20. Black mulberry transferprint ceramic observed at Site 41 HR 1236 ............................ 30

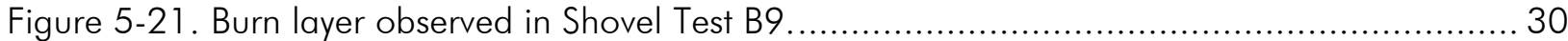

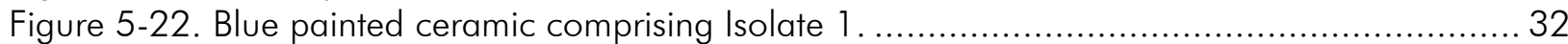

Figure 5-23. Pile of roofing shingles identified near a modified natural gully just south of Brock Park in Trail Segment GR03/Field A. View is to the south............................................................... 32

Figure 5-24. Rubble pile of cement slab located near a trail adjacent to Green Dolphin Street, Trail

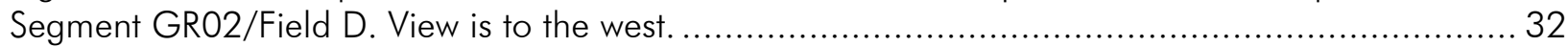

\section{LIST OF TABLES}

Table 5-1. Previously recorded archaeological projects within 1.6 kilometers of the APE................. 16 Table 5-2. Previously recorded archaeological sites within a 1.6-kilometer (1-mile) radius of the APE.

. . . .

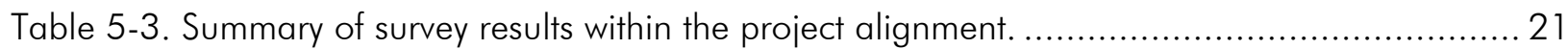

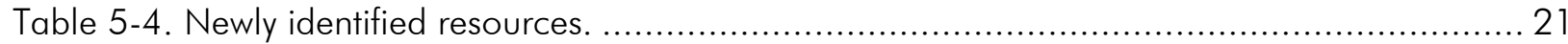

Table 5-5. Provenience of Subsurface Materials Identified within Site 41HR1 235 ......................... 27

Table 5-6. Provenience of Subsurface Materials Identified within Site 41HR1 236 ......................... 31

Table 6-1. Summary of recommendations for resources identified within the APE........................... 33 
Clark Condon Associates, Inc. (Clark Condon), of Houston, Texas, on the behalf of their client, Houston Parks Board, contracted with Gray \& Pape, Inc. (Gray \& Pape), of Houston, Texas, to perform an archaeological survey on approximately 10.8 kilometers $(6.7$ miles) of property proposed for the construction of trail system sections along Lower Greens Bayou in Harris County, Texas (Figure 1-1). The proposed trail development is part of the Houston Parks Board's Bayou Greenways 2020 Project. Because the proposed trail development occurs on publicly owned properties and on the behalf of the Houston Parks Board, a political subdivision of the state of Texas, a Texas Antiquities Code Permit (TACP) was required prior to survey. All work was completed under TACP \# 8328, which was issued by the Texas Historical Commission (THC) on February 14, 2018.

The goals of the survey were to determine if the project would affect any previously identified archaeological sites, to establish if previously unidentified buried archaeological resources were located within the project's Area of Potential Effects (APE), and if so to provide management recommendations for these resources. All fieldwork and reporting activities were completed according to state (the Antiquities Code of Texas) guidelines.

\subsection{Project Overview}

Both project area segments (Segment GR02 and Segment GR03) are located on the Jacinto City, Texas, United States Geological Survey (USGS) 7.5-minute topographic quadrangle map (USGS 1982). Segment GRO2 is approximately 2.9 kilometers (1.8 miles) long and extends from Strickland Park to Highway 90. Segment GR03 is approximately 7.9 kilometers (4.9 miles) long and extends from Highway 90 to Brock Park.
Trail construction will take place on the two segments within a construction corridor that typically measures 9 meters (30 feet) wide except at culvert crossings where it could expand to 15 to 23 meters (50 to 75 feet). In total, the project will encompass approximately 9.6 hectares (23.7 acres). The depth of the project's impacts is not expected to reach below 0.9 to 1.5 meters (3 to 5 feet). These dimensions will define the archaeological APE.

\subsection{Report Organization}

This report is organized into seven numbered chapters and two lettered appendices. Chapter 1.0 provides an overview of the project. Chapter 2.0 presents an overview of the environmental setting and geomorphology. Chapter 3.0 presents a discussion of the cultural context associated with the APE. Chapter 4.0 presents the research design and methods developed for this investigation. The results of this investigation are presented in Chapter 5.0. Chapter 6.0 presents the investigation summary and provides recommendations based on the results of field survey. A list of literary references cited in the body of the report is provided in Chapter 7.0. Maps showing project results are presented in Appendix A. A log of the shovel tests is provided in Appendix B.

\subsection{Acknowledgements}

Fieldwork was conducted as access became available and thus required several mobilizations that took place between April 10 and 13, 2018, May 14, 2018, April 17, 2019, June 13, 2019, and January 7, 2020. Fieldwork was conducted by Sr. Principal Investigator Tony Scott, Archaeologist Jacob Hilton, and Crew Chiefs Stephanie Bush and Amanda Kleopfer. The fieldwork required 128 person-hours to complete. The report was prepared by Mike Quennoz, Jacob Hilton, Amanda Kleopfer, and Tony Scott. Graphics were produced by Tony Scott. Jessica Bludau produced and edited the report. 


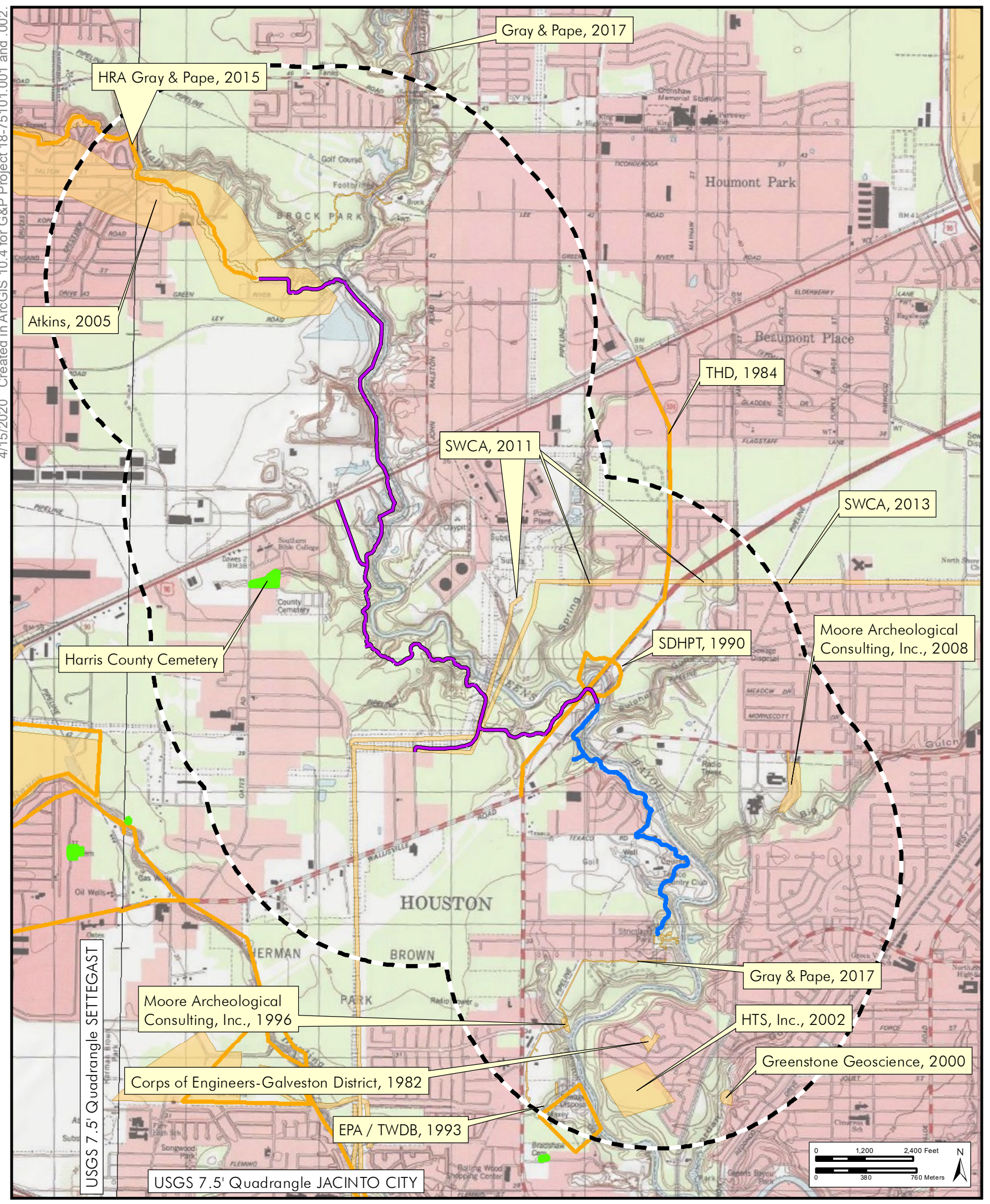

Figure 1

Project area location in Harris County, Texas.

GRAY \& PAPE
Project Location (Segment)

GR02

- GRO3 I Study Radius (1.6-km/1 -

HERITAGE MANAGEMENT Previously Recorded Area Survey Previously Recorded Linear Survey

Cemetery Boundary USGS Quadrangle Boundary

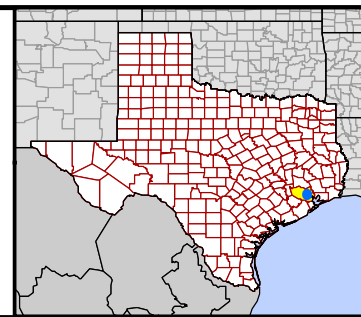




\subsection{ENVIRONMENTAL CONTEXT}

\subsection{Physiography and Geomorphology}

The Texas Coastal Plain makes up part of the larger Gulf Coastal Plain, a low, level to gently sloping region, extending from Florida to Mexico. The Texas Coastal Plain reaches as far north as the Ouachita uplift in Oklahoma, and as far west as the Balcones escarpment in central Texas. The basic geomorphological characteristics of the Texas coast and associated inland areas, which includes Harris County, resulted from depositional conditions influenced by the combined action of sea level changes from glacial advance in the northern portions of the continent, and subsequent downcutting and variations in the sediment load capacity of the region's rivers. Locally, Harris County is underlain by relatively recent sedimentary rocks and unconsolidated sediments ranging in age from the Miocene to Holocene (Abbott 2001; Van Siclen 1991).

The project area is located within the Coastal Prairie physiographic province (University of Texas, Bureau of Economic Geology [UT-BEG] 1997) and within the Western Gulf Coast Plain ecoregion (UT-BEG 2010) with elevation range between 15 to 76 meters (50 to 250 feet) above mean sea level (AMSL). The project area is located on the Houston Sheet of the Geologic Atlas of Texas and is underlain by the Beaumont Formation, which is composed of Pleistocene deposits (Barnes 1982). Although older geologic units have been identified in the region (Abbott 2001; Barnes 1982; Van Siclen 1991), units relevant to the study of long-term human occupation in modern-day Harris County include the Beaumont Formation, generally believed to predate human occupation in the region, and the so-called "Deweyville" terraces, positioned stratigraphically between the Beaumont and Recent deposits. These terraces date to between 100,000 to 4,000 years ago, and are characterized as consisting "of up to three inset fluvial terraces... (distinguished by the presence of)... large looping meander scars..." indicative of watercourses capable of fluvial action and discharge markedly greater than that seen today (Abbott 2001: 16). Overlaying these deposits may be relatively thick or thin Holocene deposits, laid down in the Harris County area by alluvial or eolian processes, or potentially marshy environments. The Willis Formation is the oldest geological formation in the area and is found in the northwestern part of the county. It is probably transitional in age from the Pliocene to the Pleistocene, or 1 million to 3 million years old.

Topographic relief is the result of downcutting of sediments from fluvial action associated with the many rivers, bayous, and creeks within and around Harris County. Major drainages include the Brazos River to the west, the Colorado River to the north, and the San Jacinto River to the east. Creeks and bayous that border or dissect Harris County include Spring and Cypress creeks to the north, Cedar Bayou to the east, Buffalo Bayou in central Harris County, and Clear Creek, Brays Bayou, and Keegans Bayou to the south. Two such streams, Halls Bayou and Greens Bayou, are present within the current APE.

\subsection{Soils}

There are five mapped soil types within the APE of Segment GRO2: Texla silt loam, Dylan clay, Bacliff clay, Bacliff-Urban land complex, and Ozan-Urban land complex. There are two mapped soil types within the APE of Segment GR03: Atasco fine sandy loam and Texla silt loam (Soil Survey Staff, Natural Resources Conservation Service, United States Department of Agriculture [SSS NRCS USDA] 2018).

Texla series soils are very deep, somewhat poorly drained soils formed in loamy fluviomarine deposits of late Pleistocene age. A typical profile presents a top 10 centimeters (4 
inches) of dark grayish brown (1OYR 4/2) silt loam. Between 10 and 23 centimeters ( 4 and 9 inches) is a light yellowish gray silt loam that transitions to a yellowish brown (10YR 5/6) silty clay loam extending to 56 centimeters (22 inches) below the surface. From 56 to 84 centimeters (22 to 33 inches) is a grayish brown (10YR 5/2) clay, underlain by a gray (10YR 6/1) clay to a depth of 119 centimeters (47 inches) below the surface. Finally, a light gray (10YR $7 / 1$ ) clay loam extends to 203 centimeters (80 inches) below the surface (SSS NRCS USDA 2018). The Texla soils are predominant in Segment GRO3 from Wallisville Road to Mayco Mufler on Highway (Hwy) 90.

Dylan series soils are generally very deep and moderately well drained soils, formed in clayey alluvium. A typical profile has a surface layer of dark grayish brown (1OYR 4/2) clay extending to 10 centimeters ( 4 inches) below the surface. From 10 to 132 centimeters (4 to 52 inches) is a yellowish brown (10YR 5/4) to brownish yellow (10YR 6/6) clay with increasing masses of oxidized iron with depth. This is underlain by a strong brown (7.5YR 5/6) clay to a depth of 203 centimeters (80 inches) below the surface (SSS NRCS USDA 2018). The Dylan soils underlie the APE from near the intersection of Harvey Lane and Green Dolphin Road to the meander of Greens Bayou southeast of the Texaco Country Club.

The Baycliff series soils are very deep and poorly drained soils that formed in clayey fluviomarine deposits derived from the Beaumont Formation. A typical profile has a surface horizon of dark gray (1OYR 4/1) clay to a depth of 23 centimeters ( 9 inches). The subsoil extends from 23 to 203 centimeters ( 9 to 80 inches) and consists of gray (10YR 5/1 to 10YR 6/1) clay. The Bayliff and Baycliff-Urban land complex underlie the APE in Segment GR02 from Wallisville Road to the Texaco Country Club (SSS NRCS USDA 2018). The Bacliff series has low geoarchaeological potential (Abbott 2001).

The Ozan series consists of deep, poorly drained, slowly permeable soils that formed in loamy alluvium. In undisturbed contexts, a representative soil profile contains six strata (AEg-Btg/Eg-Btg1-Btg2-BCg) from 0 to 183 centimeters (0 to 72 inches). The Ozan-Urban land complex underlies the APE in Segment GR02 from Strickland Park to the southeastern end of the Texaco Country Club (SSS NRCS USDA 2018). The Ozan series has moderatehigh geoarchaeological potential (Abbott 2001).

Atasco series soils are very deep, moderately well drained soils formed in loamy fluvial deposits of Pleistocene age. A typical profile has a surface layer of brown (10YR 5/3) fine sandy loam extending to 15 centimeters ( 6 inches) below the surface and underlain by a light yellowish brown (10YR 6/4) fine sandy loam to a depth of 36 centimeters (14 inches) below the surface. Between 36 and 54 centimeters (14 and 21 inches) is a red (2.5YR 4/6) and brownish yellow (10YR 6/6) clay. Below this, a brownish yellow (10YR 6/6) and red (10R 4/6) sandy clay transitions into a light gray (N7/) and red (10YR 5/8) sandy clay loam, terminating at 179 centimeters (71 inches) below the surface. Finally, to a depth of 203 centimeters (80 inches) is a light greenish gray (10YR 8/1) and yellowish red (5YR 5/6) clay (SSS NRCS USDA 2018). The Atasco series has low geoarchaeological potential (Abbott 2001). The Atasco soils are predominant in Segment GR03 from Mayco Muffler on Hwy 90 to Ley Road.

\subsubsection{TXDOT-Houston District's PALM}

The Texas Department of Transportation (TxDOT)-Houston District's Potential Archeological Liability Map (PALM) covers Harris and other counties in the Greater Houston area and is based on a combination of data including soil associations, landform types, cultural and natural resource distribution, and historic and modern land use data. The PALM is a Cultural Resource Management tool that predicts the likelihood of detecting deeply buried intact cultural resources in various topographic settings around Houston. The 
model also recommends the type of archaeological survey strategy that should be implemented for a given PALM unit, of which there are seven major groupings.

- 0 - Water. No survey recommended.

- 1 - Surface Survey Recommended, Deep Reconnaissance Recommended if Deep Impacts Are Anticipated.

- 2 - Surface Survey Recommended, No Deep Reconnaissance Recommended.

- 2a - Surface Survey of Mounds Only; No Deep Reconnaissance Recommended.

- 3 - No Surface Survey Recommended, Deep Reconnaissance Recommended if Deep Impacts Are Anticipated.

- $3 a$ - No Surface Survey Recommended, Deep Reconnaissance Recommended only if Severe Deep Impacts Are Anticipated.

- 4 - No Survey Recommended.

The current project does not require TxDOT review. The PALM modeling units were, however, referred to as part of the desktop assessment and used to plan an appropriate field strategy. A majority of the APE within Segment GR02 is modeled as belonging to Map Units 1 and 2 with about 0.84 kilometers (0.52 miles) belonging to Map Unit 4. The majority of Segment GRO3 is mapped as Unit 1 with shorter portions mapped as Units 2 and $3 a$. Only 0.47 kilometers (0.29 miles) of Segment GR03 is mapped as Unit 4. Not coincidentally, those portions of the APE for which surface survey or deep reconnaissance is recommended are closer to the channel of Greens Bayou where there is greater potential for buried and intact cultural resources. In contrast, those areas for which no survey is recommended underlie or are immediately adjacent to the houses along Green Dolphin, the Texaco Country Club and Brock Park where intact artifacts or features are unlikely to be found due to ground disturbances.

\subsection{Natural Environment}

\subsubsection{Flora and Fauna}

Present-day Harris County is located near the western edge of the Austroriparian biotic province and is situated in the Upland Prairies and Woods subregion of the Gulf Coast Prairies and Marshes Region (Abbott 2001). Evidence from pollen analysis in Central Texas suggests that, at least during the Late Pleistocene, the area may have been populated by vegetative species that were tolerant of a cold weather environment. Climactic fluctuation during the Holocene would eventually result in a gradual trend towards warmer weather, similar to that seen today (Abbott 2001).

Late Pleistocene flora may have included populations of spruce, poplar, maple, and pine (Holloway 1997), in an oak woodland environment that would eventually transition to an oak savanna in the late Holocene (Abbott 2001). Fauna during this time would include currently present species such as white-tailed deer and various smaller game, as well as bison, and, in localized areas, pronghorn sheep and the American alligator (Abbott 2001).

The modern vegetative community associated with this region consists of a diverse collection of primarily deciduous trees and undergrowth (Abbott 2001). Modern land alteration activities, especially those associated with agriculture, have resulted in the removal of native plant species from the area. Identified trees may include water oak, pecan, various elms, cedar, oaks, sweetgum, and mulberry, to name a few. Honeysuckle, dewberry, yaupon, and blackberry are common, as are indiangrass and bluegrasses (Abbott 2001).

The modern faunal community includes mammals such as deer, squirrel, opossum, raccoon, skunk, and various small rodents; numerous bird species; and reptiles, including the Texas rat snake, the western cottonmouth, the kingsnake, and turtle species. Black bear 
and bison were present occasionally in the past (Abbott 2001).

\subsubsection{Climate}

Harris County's close proximity to the Gulf of Mexico tends to influence the temperature, rainfall, and relative humidity of the region. Winds usually trend from the southeast or east, except for in winter months when high-pressure systems can bring in polar air from the north. Average temperatures in the summer can reach well above 30 degrees Celsius 90 degrees Fahrenheit), and are often accompanied by equally high humidity. Although winter temperatures can reach below 0 degrees Celsius (30 degrees Fahrenheit), below freezing temperatures usually occur on only a few days out of every year and are typically restricted to the early morning hours (Wheeler 1976).

Rainfall is even throughout the year, with an average monthly distribution ranging from between 43 centimeters (17 inches) to trace amounts; rainfall comes primarily from thunderstorms (Wheeler 1976), which tend to be heavy but of short duration.

\subsection{Land Use}

While areas adjacent to both proposed trail segments have experienced some development, much of the landscape overlapped by the alignment is undeveloped and the bayou has been unmodified (Figure 2-1).
Segment GR02 borders multiple residential and recreational spaces along Greens Bayou; however, much of the APE is currently unused. It begins in the south in Strickland Park and extends through riparian woodland along the bayou and further north along the edge of the Texaco Country Club. Here, the APE is collocated with some of the existing trails or walkways from the country club. At Texaco Road, the APE extends northeast through a buried utility corridor before turning northwest and running parallel to Green Dolphin Road. Continuing northwest, the APE crosses Wallisville Road and two additional buried utility lines before terminating at Hwy 90 .

Segment GR03 borders or crosses multiple commercial or municipal zones, however, like Segment GRO2, much of it remains unused. Following the meandering channel of Greens Bayou, Segment GR03 crosses the Alamo Ready Mix property just north of Hwy 90. From here, the APE continues northwest and crosses a wide utility corridor with multiple rows of electricity pylons. Continuing northwest and up to the Mayco Muffler property, the APE crosses several gullies and ravines through riparian woodland along Greens Bayou. Here, the APE meanders back northeast along the bayou and the edge of the Safe Park property, the massive landfill and retention basin before turning west and terminating in Brock Park. 


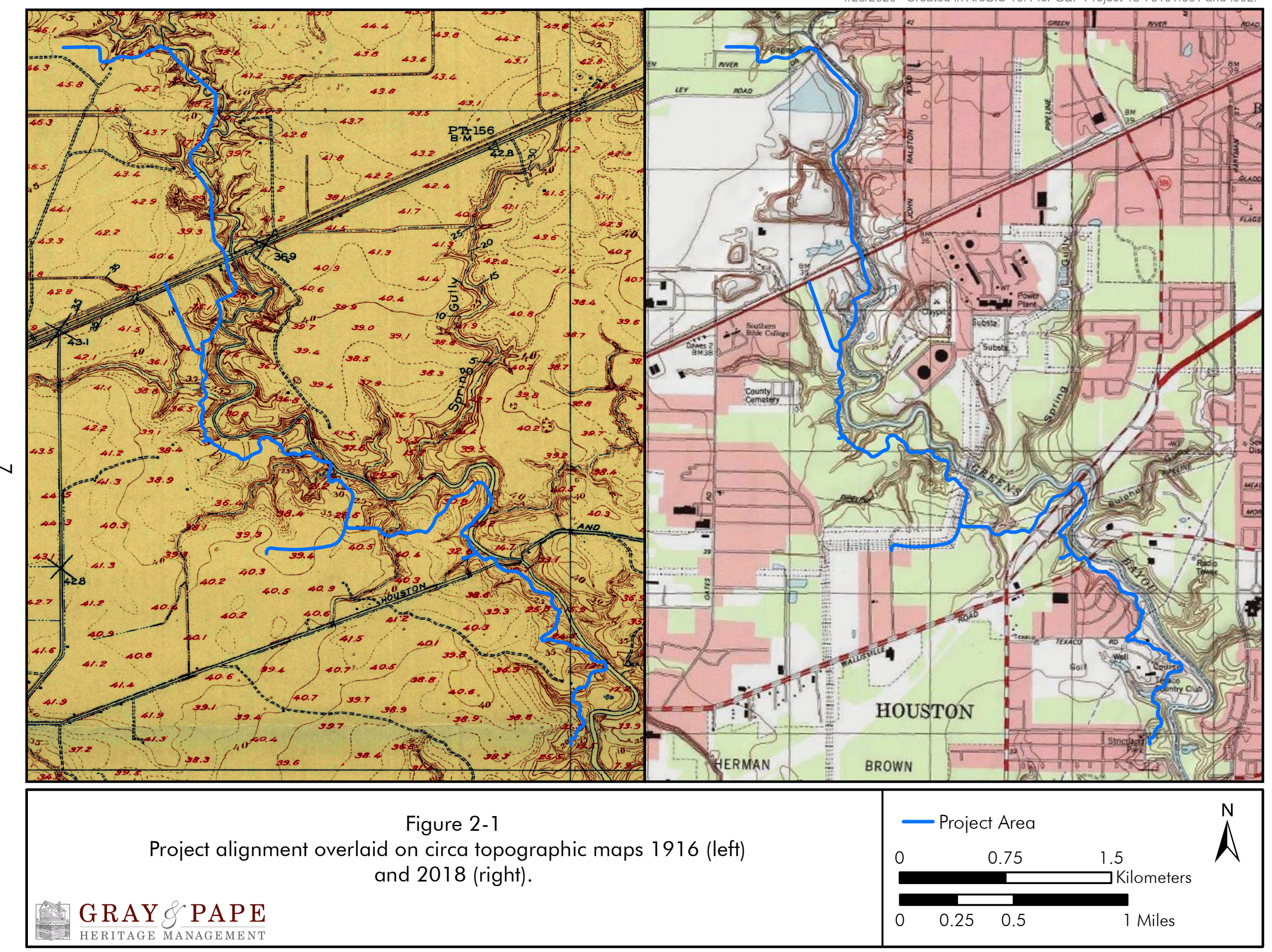




\subsection{CULTURAL CONTEXT}

\subsection{Prehistoric Context}

Traditionally, Southeast Texas has been viewed as a buffer zone between cultural regions in prehistoric times. Patterson (1995) describes the archaeological record in this area as being an interface between the Southern Plains and the Southeast Woodlands. Along similar lines, both Shafer (1975) and Aten (1984) have categorized the Post-Archaic archaeological record of this region as Woodland. This categorization is not meant to literally invoke the exact cultural patterns and chronology of the Woodlands culture found to the east. Aten (1984:74) summarizes his concept by saying, "it loosely connotes activities by populations on a geographic as well as a cultural periphery of the southeastern Woodlands."

Dee Ann Story (1990) has suggested that the culture of Southeast Texas is distinctive enough so as to merit a separate designation by the Late Prehistoric. The Mossy Grove cultural tradition is a heuristic concept based on technological similarities shared by groups in this region. The primary marker of this technological tradition is the plain, sandy-paste Goose Creek pottery that is found in this region from the Early Ceramic through Early Historic periods.

Ethnic affiliations for the region are not entirely clear. Aten (1983) has defined the Brazos Delta-West Bay, Galveston Bay, and Sabine Lake archaeological areas and suggests that they may correlate with the Historic territories of the Coco, Akokisa, and Atakapa groups, respectively. Similarly, historic reconstructions of the inland subregion suggest a number of possible group affiliations (Story 1990). The historic economic inland/coastal cycle of the Akokisa, which stretched from Galveston Bay to the San Jacinto River basin, may mean that archaeological materials in the Lake Conroe area are affiliated with this group. Alternately, these remains may be associated with the Bidais who occupied territory immediately to the north of the Akokisa groups. At this point in time it is not possible to identify the cultural affiliation of the groups that inhabited the inland subregion. In part, this is a function of the dynamic nature of this region in which a number of cultural traditions met and diffused.

The Southeast Texas region is divided into inland and coastal margin subregions, which have archaeologically distinctive subsistence patterns, settlement patterns, and artifact types. Archaeological and historic evidence suggests that some groups exploited inland resources year-round, while other groups spent parts of the year both inland and on the coast.

Based on aspects of material culture, researchers have identified six archaeological time periods associated with Native Americans in the Southeast Texas region; in general, these include the Paleoindian, Archaic (with Early, Middle, and Late subdivisions), Ceramic, Late Prehistoric, Protohistoric, and Historic Indian. Archaeologists within the region agree on the general framework of cultural time periods, while disagreeing on the temporal boundaries of these periods. Despite these differences, the chronologies developed by researchers are based primarily on changes in projectile point technologies within the region and the introduction of pottery. It is generally recognized that a broad-based hunting and gathering lifestyle was utilized throughout all time periods. For the purpose of this document the temporal boundaries of prehistoric periods will be primarily based on Story (1990) and Aten (1983) and this information is merged with the archaeological data here to give a complete picture of life on the Upper Texas Coast.

\subsubsection{Paleoindian Period}

Along the Upper Texas Coast, the Paleoindian period (termed the Early Cultures by Story) begins around 12,000 Before Present (B.P.) and 
ends near 9,000 to 8,000 B.P. (Aten 1983; Story 1990). Evidence is sparse for Paleoindian habitation, and much of what is known about the period in the area comes from a compilation of materials gathered from the state of Texas and North America. At the close of the Pleistocene, large game hunters crossed the Bering Strait, and within a few millennia had penetrated into South America (Culberson 1993; Newcomb 1961). The Paleoindian people traveled in small bands (Culberson 1993) and were mega-fauna hunter-gatherers with the bulk of their meat protein derived from mammoths, mastodons, giant bison, and giant sloths. These groups carried with them an easily recognizable stone tool material culture, though admittedly, little is known about their wooden or bone tools and clothing types. The later Folsom Culture developed a very efficient toolkit that was apparently designed to be portable leading to theories that these people were following buffalo herds across the plains. However, the widespread use of Folsom technology suggests that the technology spread beyond the area for which it was initially designed. Isolated Paleoindian artifacts found across southeastern Texas include Clovis, Angostura, Scottsbluff, Meserve, Plainview, and Golondrina point types (Aten 1983).

The Transitional Archaic period begins about 9,000 B.P. and ends around 7,500 B.P. (Aten 1983; Story 1990). This stage is also poorly represented in the archaeological work in the area but isolated finds of Bell/Calf Creek, EarlySide Notched, and Early Expanding Stemmed dart points are attributed to this time period.

\subsubsection{Archaic Period}

With the retreat of the glaciers (the Hypsithermal period), the mega-fauna upon which the Paleoindian peoples depended gradually became extinct. This shift in food supply is seen as the pivotal transition point between the Paleo and Archaic periods (Biesaart et al. 1985; Culberson 1993; Newcomb 1961). Though dates often disagree (ranging from 8,000 B.C. marking the beginning of the Early Archaic
[Culberson 1993], to Aten [1984] stating that the transition from Late Archaic to Late Prehistoric-Woodland began around A.D. 100), there are three progressive stages recognizable during the Archaic period: the Early, Middle, and Late.

Much of what is known about the Early Archaic peoples indicates that they were small, isolated bands of hunter-gatherers that remained in relatively restricted regions (Aten 1984). With the loss of the mega-fauna as a food source, the Early Archaic peoples adopted the hunting of smaller game such as bison and deer and increased their reliance on foraging (Culberson 1993). The material record fits the transitional makeup of this period because there was a dramatic shift from the large spear points of the Paleoindian period to a reliance on smaller dart type points. Diagnostic designs for this period are Dalton, San Patrice, Angostura, Golondrina, Merserve, Scottsbluff, Wells, Hoxie, Gower, Uvalde, Martindale, Bell, Andice, Baird, and Taylor (Turner and Hester 1993). These points are much more crudely made than their Paleo precursors but remain designed for use on a spear shaft.

The Middle Archaic period saw the largest growth in technology and in the number of stone tools utilized. Specialized tools appeared for the milling of wild plant foodstuffs (Culberson 1993) along with a large assortment of tools for food preparation and procurement. Gravers, scrapers, axes and choppers, knives, drills and polished stone tools, also known as ground stone tools, began to appear in large quantities (Newcomb 1961). Diagnostic points such as Gary, Kent, Palmillas, Nolan, Travis, Belvedere, Pedernales, Marshall, Williams, and Lange dominate the spectrum of dart points from the Middle Archaic period (Turner and Hester 1993; see also the Edwards Plateau Aspect [Newcomb 1961]). The advent of the atlatl also seems to be placed within this period (Culberson 1993).

The Late Archaic period saw a dramatic increase in the population densities of Native 
American groups. Human habitation of areas rich in diverse flora and fauna intensified, as did the variety of materials and artifacts (Culberson 1993; Aten 1984). Late Archaic peoples began relying heavily on foraging tubers, berries, and nuts and hunting small game such as deer, rabbits, and raccoons, as well as fish and shellfish, and birds. Groups became socially more complex than earlier periods and the result was an increasing intercommunication with neighboring groups. Culberson (1993:55) states that a "Lapidary Industry" developed in which stone artifacts were made from exotic materials (jasper, hematite, quartz, shale, slate, etc.) acquired from sources great distances away. These materials were fashioned into an increasingly complex array of household goods such as celts, plummets, banner stones, mortars and pestles, and pendants; also, during this period there is an increase in the occurrence of sandstone bowls (Culberson 1993). Diagnostic points of this period are difficult to distinguish from those of the Middle Archaic. Gary and Kent points remain prevalent in southeast Texas, while other points such as Marcos, Montell, San Gabriel, Mahomet, Fairland, and Castroville also appear at times (Turner and Hester 1993).

The Archaic period in southeast Texas ends with the adoption of ceramic technology at the beginning of the Ceramic period. Patterson (1995) places the beginning of the Early Ceramic period on the Texas coast from 100600 A.D. Aten (1983) placed the appearance of pottery in the Galveston Bay area approximately 100 A.D. The ceramic chronology of the inland areas parallels that of the coast; however, it does not manifest until several centuries later. The inland areas generally lack the earliest ceramic types present in the coastal region as well as some of the later ceramic types (Aten 1983; Story 1990). As a result of trade networks or stylistic/manufacturing influences, it appears that ceramic traits moved from the coast to the inland areas and from the east to the west (Aten 1983).

\subsubsection{Late Prehistoric}

The transitional period between Late Archaic and Woodland-Late Prehistoric is a period marked by an intensification of group dynamics across Texas. The advent of the bow and arrow is believed by most (Aten 1984; Culberson 1993; Newcomb 1961) to be from this period, though some may place it later. Most importantly for archaeological investigations, the first signs of pottery begin to emerge at sites from this period (Aten 1983). Although the amount and variety of pottery intensifies during the Late Prehistoric, it is an excellent way of determining the terminus post quem of a site. Fishing, bison hunting, and the collection of wild flora intensifies beyond the level of the Late Archaic period during this stage, but there is no sufficient data to demonstrate the initial advent of sedentary agricultural. The diagnostic points of this period are Catahoula, Friley, Alba, and Bonham (Turner and Hester 1993).

The Late Prehistoric (also known as Woodland and Ceramic periods) continue from the end of the Archaic period to the historic period ushered in by the Spanish Missions and Anglo-American settlers. During this period there is a shift to the almost total use of arrow points such as Perdiz and, later, Scallorn, and a wide variety of ceramic types. According to Aten (1984), there are nearly 18 different types of pottery from this period currently identified for the east Texas Coast alone based on temper, paste, and design.

Goose Creek and other sandy paste pottery types are often recovered from Ceramic period and Late Prehistoric sites throughout southeast Texas. Goose Creek appears in Aten's coastal chronology to greater or lesser extents in nearly every period, particularly Mayes Island, Turtle Bay, Round Lake, and the later Orcoquisac periods. Because of the predominance of sandy paste pottery across the region, Story (1990) has suggested the Mossy Grove Tradition as an encompassing cultural tradition for the area. Other ceramic forms that occur in the region 
include grog-tempered, stamped, and bonetempered pottery (Patterson 1996).

\subsubsection{Protohistoric Period to the Post- Contact}

It is during this period that peoples known today as the Caddo, Attakapans, and Bidai, to name a few, are identifiable both culturally and materially. This is mostly due to the historical sources of the seventeenth through the nineteenth centuries that aid in the reconstruction of the past cultures in the area. In order to better understand the complexity of the region's cultures, researchers turn to historical sources to get an understanding of the peoples who first occupied the southeast Texas. Hernando De Soto encountered the Native Americans of the region during his expedition in 1542 (Hudson 1976); it was the first recorded meeting with the Caddo peoples. The first expeditions by La Salle in 1687 and the subsequent settlement in the eighteenth century by Europeans continued to document the presence of Native American groups in the area (Aten 1984). French traders and Spanish missionaries encountered the Hasinai, also known as the Neches Angelina, who became allies of the Spanish against the western Apache tribes (Newcomb 1961). The later historical sources identify the Hasinai as one of the two main groups in the area of eastern Texas that fall under the Caddo culture (the primary culture that dominated the Piney Woods area), the other of which is the Kadohadacho (La Vere 1998; Gregory 1986).

The loose cultural group, known as the Attakapans, dominated the majority of the land north of present-day Harris County in what is now Montgomery County. Their language group extended from the Gulf coast to the Trinity and San Jacinto Rivers and they had much in common with the coastal group known as the Karankawa (Aten 1984). The Attakapans were subdivided into regional groups. The Akokisas dwelled primarily on the shores of the Trinity and San Jacinto Rivers. The Patiris group occupied the land north of the San Jacinto valley. The Bidai group dominated the Trinity Valley and to their north was the small group known as the Deadoso. Most of what is known about the Attakapans culture comes from the early accounts of the French explorer DeBellise. They are described as primarily hunter-gather groups who relied somewhat on agriculture and fishing (Sjoberg 1951).

In the seventeenth and eighteenth centuries, the Spanish and French used the Native American groups as pawns in the two nations' quest to settle the area (Newcomb 1961). Most destructive for all native groups in the region was the influx of European diseases. When Anglo-American settlers began moving into the area in mass around the 1850s, disease and warfare had decimated the groups to near extinction.

\subsection{Historical Context}

Harris County was formed as Harrisburg County on December 22, 1836. The county was renamed Harris in December 1839 to honor John Richardson Harris, an early pioneer who had established Harrisburg in 1826, the first town site in the county. Harrisburg was established at the confluence of Buffalo Bayou and Brays Bayou and by the 1830s had become the major port of entry for the region and a transportation hub. Roads ran northwest to the Brazos communities of San Felipe and Washington, east to the ferry landing that crossed the San Jacinto, and west paralleling Brays Bayou to the Oyster Creek Community near present day Stafford in Fort Bend County (Henson 2017).

Under Mexican rule, the area surrounding Harrisburg was known as the San Jacinto District. The district stretched east from Lynchburg on the San Jacinto River, west to the location of present-day Richmond, and from Clear Creek in the south to Spring Creek in the north. Harrisburg County encompassed this same territory with the addition of Galveston Island. The modern boundaries of Harris 
County were established in 1838 (Henson 2017).

The lands that would become Harris County comprised the southeastern border of Austin's Colony. In July of 1824, 29 titles were granted to lands in future Harris County, with an additional 23 grants made between 1828 and 1833. These original grants concentrated mainly on the watercourses of the region (Henson 2017). The early settlers in the region were mostly from the southern U.S. who brought with them their African slaves. In the 1840s, large numbers of German and French immigrants settled in Harris County. The Hispanic presence in the region was relatively sparse prior to an influx of immigrants following the Mexican Revolution reflecting the ephemeral nature of Spanish and Mexican colonization.

The founding of the city of Houston by Augustus and John Allen was announced in a newspaper advertisement in August 1836. The brothers managed to convince the delegates of the first Texas Congress to establish the yet-to-be-built Houston as the first, albeit temporary (18371840), capital of Texas. In 1837, Houston also became the seat of Harrisburg County. The town was laid out on a grid plan with streets running parallel and perpendicular to Buffalo Bayou near the confluence of White Oak Bayou. The town grew rapidly from 12 inhabitants and one log cabin in January 1837 to 1500 people and 100 houses four months later (Henson 2017).

Initially, the city was not segregated, and slaves lived scattered throughout the city's neighborhoods. There was a separate social structure for the whites and subordinate blacks which, continued beyond the Civil War and Emancipation. Schools, churches, and businesses continued to be segregated and by the end of the nineteenth century residential segregation was also present. Separate white, black, and later on Hispanic neighborhoods divided the city.
The immigrants that came to the area following the Civil War founded settlements along the rail lines that bisected the county. The Houston communities of Pasadena, Deer Park, Houston Heights, Bellaire, Webster, La Porte, South Houston, and Genoa developed in this manner and were eventually annexed into the city of Houston. By the 1930s, Harris County was the largest county and Houston was the largest city in Texas (Henson 2017).

By the mid-nineteenth century, Houston and Harris County had become a center of commerce. Products were imported into the Texas hinterland through Houston after being offloaded from ocean going ships in Galveston. Exports included agricultural products such as cotton, corn, and cow hides. The town became a railroad hub with six railways spreading from 80.5 to 160.9 kilometers (50 to 100 miles) to the northwest, east, west, south, and southeast. In 1873, Houston joined the national rail network when the Houston and Texas Central reached Denison (Henson 2017).

The expansion of Buffalo Bayou was essential to the commercial life of Houston and a number of private ventures were undertaken over the years to widen and deepen the channel. The United States Army Corps of Engineers (USACE) took control of the project in 1881, eventually creating the 15.2-meter (50-foot) deep Houston Ship Channel from Galveston Bay to a turning basin above Brays Bayou. Additional public works projects included the creation of the Lake Houston reservoir in 1954 to reduce the dependence on subsurface water, the use of which had caused up to 3 meters (9 feet) of subsidence surrounding the confluence of Buffalo Bayou and the San Jacinto River. In 1935, the Harris County Flood Control District was established and infrastructures such as the Addicks and Barker dams in western Harris County were constructed. Since this time, channelization projects completed along Houston area bayous have disturbed any archaeological sites in their path. However, isolated and undisturbed areas along these 
watercourses may still contain intact deposits (Abbott 2001:101).

The discovery of oil at Spindletop made Houston an important center for the petroleum industry. The Ship Channel's inland location made it safe from Gulf storms and refineries began lining the banks in 1918. By 1929, 40 oil companies had offices in Houston. The outbreak of World War II created a demand for products made of petrochemicals. The city has gone on to become one of the two largest petrochemical concentrations in the United States (Henson 2017). 


\subsection{FIELD METHODOLOGY}

This cultural resource investigation was designed to identify and assess new and already recorded cultural resources that may be impacted by the proposed project. Desktop assessment and modeling were performed prior to initiating field investigations in order to better understand cultural, environmental, and geological settings. Results of the desktop assessment were then used to develop the field methodology.

\subsection{Site File and Literature Review}

The background literature search included a review of previously conducted cultural resource surveys in the vicinity of the proposed project area, and of any historic document pertaining to the history of the area. Site file research was performed in order to identify all previously recorded archaeological sites within a 1.6kilometer (1-mile) study radius of the project area and any recorded historic structures eligible for the National Register of Historic Places (NRHP) or State Antiquities Landmark (SAL) listing located adjacent to the project area. Site file research was done by reviewing records maintained by the Texas Archeological Research Laboratory in Austin, Texas, and by consulting online research archives maintained by the THC.

Historical topographic and aerial maps were reviewed in order to identify any historic structures that might be located close to or within the project area. Historical maps of Texas and Texas counties were reviewed in order to better understand the history of the region and to identify any potential historic trails and important historic sites located or crossing the project area. Historical topographic maps and aerial photographs were reviewed to identify potential residential and other structures located within the project area.

\subsection{Field Methods}

\subsubsection{Intensive Pedestrian Survey}

Each segment was divided into fields by natural and/or artificial landmarks or topography. Shovel testing within each segment and field was carried out along a single transect within the 9-meter (30-foot) corridor. In high potential areas, such as those closest to Greens Bayou, shovel test intervals were spaced at 30 meters (100 feet), depending on topography and soil characteristics. The shovel test interval was increased to 60 to 100 meters (197 to 330 feet) within segments of the APE that exhibited prior disturbance. Subsurface testing consisted of the excavation of 30 - by 30 -centimeter (12- by 12 inch) shovel tests. Vertical control was maintained by excavating each shovel test in 10-centimeter (4-inch) levels. One wall of each shovel test was profiled, and the walls and floor of each shovel test were inspected for color or texture change potentially associated with the presence of cultural features. When possible, soils were screened through 0.64 -centimeter (0.25-inch) wire mesh; soils with high clay content were hand sorted in an effort to detect cultural materials in the soil matrix. Descriptions of soil texture and color followed standard terminology and the Munsell (2005) soil color charts. All the field data were recorded on appropriate field forms. All shovel tests were backfilled after excavation and documentation. The excavated shovel tests were placed on field maps and points were taken with Global Positioning System (GPS) if the strength of the signal permitted.

\subsubsection{Site Delineation}

If new cultural resources were encountered, systematic steps were taken to define their extent, limits, and general character within the confines of the APE. Additional delineation shovel tests were excavated in four radiating directions at an interval of 5 to 10 meters (16 
to 32 feet) within the confines of the APE. In general, two sterile shovel tests were used to define a site's size and extent. At a minimum, between six and eight delineation shovel tests were excavated within the limits of the APE unless surrounding landforms or topography suggested the presence of a natural site boundary.

For each cultural resource identified, including structures or other resources within or immediately adjacent to the APE, photographs were taken of the general vicinity and of any visible features. A sketch map was prepared showing site limits, feature locations, permanent landmarks, topographic and vegetation variations, sources of disturbances, and total number of tests performed within the site. When necessary, temporally diagnostic artifacts were collected for post-field analysis. Similar materials that could be reliably dated in the field and all other non-diagnostic artifacts were photographed and placed in the backfilled shovel test or left on the surface where they were found. Locations of all positive tests and surface finds were recorded with the GPS.

\subsection{Curation}

All project records and collections are permanently held at the Center for Archaeological Studies (CAS) at Texas State University in San Marcos, Texas. 


\subsection{RESULTS OF INVESTIGATIONS}

\subsection{Result of Site File and Literature Review}

A search of the Texas Archeological Sites Atlas, maintained by the THC, determined that no historical markers or NRHP properties are located within the project area or the 1.6kilometer (1-mile) study radius around the project area (Figure 1-1). The Harris County cemetery on 5488 Oates Road is located approximately 0.70 kilometers ( 0.43 miles) west of the APE. Research also resulted in the identification of 13 archaeological projects that have been conducted within the study radius and five archaeological sites that have been recorded within the same area (Figure 1-1).

\subsubsection{Previously Recorded Surveys}

According to a search of the Texas Archeological Sites Atlas, at least 13 previous archaeological projects have been conducted within a 1.6-kilometer (1-mile) study radius of the project area (Figure 1-1; Table 5-1). These include seven area surveys, five linear surveys, and one data recovery project. Five of these surveys overlap with the current APE. In 1984, TxDOT performed a linear survey along Hwy 90 that intersected the APE. In 1990, the State
Department of Highways and Public Transportation performed a linear survey surrounding the bridged section of Hwy 90 over Greens Bayou. In 2005, Atkins North America, Inc. (Atkins) conducted a cultural resources reconnaissance survey focusing on a 600meter-wide (2,000-foot-wide) study area centered on Halls Bayou. The eastern-most portion of this assessment overlapped with the northwestern terminus of the APE. Two additional surveys performed by SWCA in 2011 and 2013 overlap with the APE near the electricity pylon corridor. The 2011 survey was for the Galena Park to Mont Belvieu Pipeline and the 2013 survey was for portions of the Texas Belle Pipeline Project. No new sites were located within the current APE as a result of these surveys.

\subsubsection{Previously Recorded Archaeological Sites}

According to a search of the Texas Archeological Sites Atlas, five previously recorded archaeological sites occur within the 1.6-kilometer (1-mile) study radius of the project area (Figure 1-1; Table 5-2). None of these sites overlap the APE and no impacts are anticipated to them a result of the project.

Table 5-1. Previously recorded archaeological projects within 1.6 kilometers of the APE.

\begin{tabular}{|c|c|c|c|c|c|c|}
\hline Project Type & $\begin{array}{c}\text { Investigating Firm/ } \\
\text { Agency }\end{array}$ & $\begin{array}{c}\text { Field Work } \\
\text { Date }\end{array}$ & $\begin{array}{c}\text { TAC } \\
\text { Permit } \\
\text { Number }\end{array}$ & $\begin{array}{c}\text { Report } \\
\text { Author }\end{array}$ & $\begin{array}{c}\text { Sponsoring } \\
\text { Agency }\end{array}$ & Report at THC \\
\hline Area Survey & N/A & N/A & N/A & $\begin{array}{c}\text { Corps of } \\
\text { Engineers, } \\
\text { Galveston } \\
\text { District }\end{array}$ & N/A \\
\hline Linear Survey & $\begin{array}{c}\text { Texas Highway } \\
\text { Department (THD) }\end{array}$ & $08 / 1984$ & N/A & N/A & NA & N/A \\
\hline $\begin{array}{c}\text { State Department } \\
\text { of Highways and } \\
\text { Public } \\
\text { Transportation } \\
\text { (SDHPT) }\end{array}$ & $05 / 1990$ & N/A & N/A & NA & N/A \\
\hline
\end{tabular}




\begin{tabular}{|c|c|c|c|c|c|c|}
\hline Project Type & $\begin{array}{c}\text { Investigating Firm/ } \\
\text { Agency }\end{array}$ & $\begin{array}{l}\text { Field Work } \\
\text { Date }\end{array}$ & $\begin{array}{c}\text { TAC } \\
\text { Permit } \\
\text { Number }\end{array}$ & $\begin{array}{l}\text { Report } \\
\text { Author }\end{array}$ & $\begin{array}{c}\text { Sponsoring } \\
\text { Agency }\end{array}$ & Report at THC \\
\hline Linear Survey & $\begin{array}{c}\text { Environmental } \\
\text { Protection Agency } \\
\text { (EPA) }\end{array}$ & 10/1993 & N/A & N/A & $\begin{array}{l}\text { EPA/Texas } \\
\text { Water } \\
\text { Development } \\
\text { Board (TWDB) }\end{array}$ & $\mathrm{N} / \mathrm{A}$ \\
\hline $\begin{array}{c}\text { Data } \\
\text { Recovery }\end{array}$ & $\begin{array}{c}\text { Moore } \\
\text { Archeological } \\
\text { Consulting, Inc. } \\
\text { (MAC Inc.) }\end{array}$ & $03 / 1996$ & 1687 & $\begin{array}{l}\text { Hubbard ef } \\
\text { al. }\end{array}$ & Harris County & N/A \\
\hline Area Survey & $\begin{array}{l}\text { Greenstone } \\
\text { Geoscience }\end{array}$ & $02 / 2000$ & 2327 & Hubbard & TWDB & $02 / 2002$ \\
\hline Area Survey & $\begin{array}{l}\text { HTS Inc. } \\
\text { Consultants }\end{array}$ & $09 / 2002$ & 2952 & Mason & $\begin{array}{l}\text { Galena Park } \\
\text { Independent } \\
\text { School District }\end{array}$ & $09 / 2002$ \\
\hline Area Survey & Atkins & $11 / 2005$ & 3947 & Norton & Harris County & $09 / 2015$ \\
\hline Area Survey & MAC Inc. & 10/2008 & 5013 & Driver & $\begin{array}{l}\text { Harris County } \\
\text { Flood Control } \\
\text { District } \\
\text { (HCFCD) }\end{array}$ & 10/2009 \\
\hline Area Survey & SWCA & $11 / 2011$ & $\mathrm{~N} / \mathrm{A}$ & Marek et al. & $\begin{array}{l}\text { USACE- } \\
\text { Galveston } \\
\text { District }\end{array}$ & $04 / 2013$ \\
\hline Linear Survey & SWCA & $07 / 2013$ & 6658 & NA & $\begin{array}{l}\text { Williams Purity } \\
\text { Pipelines, LLC }\end{array}$ & $01 / 2014$ \\
\hline Area Survey & HRA Gray \& Pape & $06 / 2015$ & 7290 & $\begin{array}{c}\text { Quennoz et } \\
\text { al. }\end{array}$ & HPB & $09 / 2015$ \\
\hline Linear Survey & Gray \& Pape & $4 / 2017$ & 7788 & $\begin{array}{c}\text { Quennoz, } \\
\text { Michael, and } \\
\text { Vincent } \\
\text { Valenti }\end{array}$ & HPB & $8 / 11 / 2017$ \\
\hline
\end{tabular}

Table 5-2. Previously recorded archaeological sites within a 1.6-kilometer (1-mile) radius of the APE.

\begin{tabular}{|c|c|c|c|c|}
\hline Trinomial & Resource Type & Sponsoring Agency & Original Recorder(s) and Date & NRHP Status \\
\hline 41 HR537 & $\begin{array}{c}\text { Prehistoric lithic scatter } \\
\text { and shell midden }\end{array}$ & $\begin{array}{c}\text { State Department of } \\
\text { Highways and Public } \\
\text { Transportation }\end{array}$ & Denton 1984 & Ineligible \\
\hline 41 HR751 & Prehistoric campsite & N/A & Sanchez et al. 1994 & Eligible \\
\hline 41 HR1038 & Prehistoric campsite & HCFCD & Ferguson 2008 & Undetermined \\
\hline 41 HR1039 & Prehistoric campsite & HCFCD & Ferguson 2008 & Ineligible \\
\hline 41 HR909 & Historic scatter & N/A & Garcia-Herreros 2002 & Undetermined \\
\hline
\end{tabular}




\subsection{Results of Field Investigations}

Survey efforts consisted of pedestrian survey and shovel testing across the entire length of the APE. For data recording purposes, the alignment was divided into seven survey fields or segments, typically demarcated by a natural or artificial feature such as a road or impassable waterway or gully (Figures 5-1 and 5-2; Table 5-3). A total of 131 shovel tests were recorded along both current and former portions of project alignment (see maps in Appendix A), of which 11 were positive for cultural material resulting in the identification of three archaeological sites and one isolate (Table 54; discussed in Section 5.2.1 below).

Approximately 0.61 kilometers (0.38 miles) of alignment were realigned to avoid resources $41 \mathrm{HR} 1235$ and $41 \mathrm{HR} 1236$. Soils varied greatly across the APE (see Appendix B) but were generally shallow. In some areas shovel test profiles consisted of 10YR $4 / 2$ to $5 / 2$ silty sandy loam underlain by $10 Y R$ R $7 / 2$ to $7 / 3$ silty sand overlying 1OYR $4 / 1$ to $5 / 1$ clay subsoil. Other shovel tests were comprised of 10YR $3 / 1$ sandy clay or loamy clay underlain by 10YR 5/3 clay. Disturbance was clear in several segments of the APE including those portions located within Brock Park, along an adjacent landfill, within paved and graveled commercial areas, adjacent to a residential area, and within the former Texaco Country Club golf course (Figures 5-3 to 5-6). The spacing between tests varied between 30 meters (100 feet) in areas with a higher archaeological potential and 90 meters (295 feet) in highly disturbed areas.

\subsubsection{Newly Identified Cultural Resources}

Three new sites were identified as a result of survey within the APE of Segment GR03, as well as one isolate. These are described below.

\subsubsection{41HR1234}

Site 41HR1234 consists of a mid-twentieth century historic midden consisting mainly of two high-density artifact scatters of bottles, one of them burned. The site was identified on April 10, 2018 and subjected to additional investigation on May 14, 2018. The site is located at the northern portion of the alignment, Segment GR03/Field A (Figures 5-1 and 5-7). Cultural materials include a large burn pile of bottles, ceramics, and brick approximately 50 meters (164.04 feet) north of North Green River (Figure 5-8). Site 41HR1234 is spread out east of a gully or ravine that drains northeast into Halls Bayou approximately 190 meters (623.36 feet) southwest of the bayou. The vegetation is predominately dense riparian woodland and the ground surface is relatively flat on both sides of the drainage. Observed materials included a glass bottle disposal pile of at least 200 bottles and jars represented.

Most bottles were fragmentary and/or burned. Sparse amounts of ceramic mug and cup fragments, at least one brick fragment, and one steak bone were also present. Much of the pile was burned, causing many of the artifacts to be distorted and discolored. Bottle types included beverages, medicinal, and beauty products. Of those that retain a legible label or stamp are: "Alamo Beverages," "Mission Beverages," "Europe's Finest Brand Italian Peppers," "Sun Crest" soda, a green Duraglas bottle base, a "Grapette Products Co" bottle in the shape of a clown, Log Cabin syrup, "Breck" shampoo, milk glass "MUM" deodorant jar, "7up", and Old Spice (Figures 5-9 to 5-12). Many of the materials including those listed above are dated to the mid-twentieth century, specifically the 1950s (Deiss 1981:95; Leif 1965:29; Lindsey 2018; Toulouse 1971:403). One of two shovel tests placed within the site boundary was positive for similar cultural materials as observed on the site surface. Test A8 contained burned glass fragments between 0 to 20 centimeters ( 0 to 8 inches) and became impenetrable due to the amount of material (Appendix B). Test A8 contained burned glass materials as observed in the surrounding area. Due to the somewhat recent age of the materials and prior damage to the materials as a result of burning, the site is considered to be low significance and have a low research value. 
REMOVED FROM PUBLIC COPY

Current and former project alignment organized by Segment and Field showing newly identified cultural resources 
REMOVED FROM PUBLIC COPY

Current and former project alignment organized by Segment and Field showing newly identified cultural resources 
Table 5-3. Summary of survey results within the project alignment.

\begin{tabular}{|c|c|c|c|c|c|c|c|}
\hline Segment & Field & $\begin{array}{l}\text { Length } \\
\text { (miles) }\end{array}$ & Conditions/Comments & Survey Method & $\begin{array}{c}\text { Shovel } \\
\text { Test } \\
\text { Count }\end{array}$ & $\begin{array}{l}\text { Resources } \\
\text { Identified }\end{array}$ & $\begin{array}{c}\text { Appendix A } \\
\text { Figure }\end{array}$ \\
\hline GR03 & Field A & 0.48 & $\begin{array}{l}\text { Approximately } 240 \text { meters is } \\
\text { within a developed portion of } \\
\text { Brock Park, the remainder is } \\
\text { moderately to densely wooded. } \\
\text { Field ends at Green River Rd. }\end{array}$ & $\begin{array}{l}\text { Pedestrian } \\
\text { Reconnaissance } \\
\text { /Intensive } \\
\text { Pedestrian }\end{array}$ & 19 & $41 \mathrm{HR} 1234$ & $A X$ \\
\hline GR03 & $\begin{array}{c}\text { Field A - } \\
\text { Abandoned } \\
\end{array}$ & 0.14 & $\begin{array}{c}\text { Moderate to densely wooded } \\
\text { area }\end{array}$ & $\begin{array}{l}\text { Intensive } \\
\text { Pedestrian }\end{array}$ & 17 & $41 \mathrm{HR} 1235$ & $A X$ \\
\hline GR03 & Landfill & 1.03 & $\begin{array}{l}\text { Located on down sloping edge } \\
\text { of a levee road that follows the } \\
\text { perimeter of the Landfill. } \\
\text { Moderately wooded. Highly } \\
\text { disturbed with signs of modern } \\
\text { trash, evidence of past flood } \\
\text { events, buried drainage } \\
\text { culverts, and other landscape } \\
\text { modifications. Field ends at a } \\
\text { impassable gully/inlet of } \\
\text { Greens Bayou. }\end{array}$ & $\begin{array}{l}\text { Intensive } \\
\text { Pedestrian }\end{array}$ & 16 & None & $A X$ \\
\hline GR03 & $\begin{array}{c}\text { Commercial } \\
\text { Properties }\end{array}$ & 1.02 & $\begin{array}{l}\text { Disturbed, heavily modified, } \\
\text { paved and graveled. }\end{array}$ & $\begin{array}{c}\text { Pedestrian } \\
\text { Reconnaissance }\end{array}$ & 0 & None & $A X$ \\
\hline GR03 & Field B & 1.00 & $\begin{array}{l}\text { Moderate to densely wooded } \\
\text { area. Field ends at an existing } \\
\text { pipeline corridor. }\end{array}$ & $\begin{array}{l}\text { Intensive } \\
\text { Pedestrian }\end{array}$ & 34 & None & $A X$ \\
\hline GR03 & $\begin{array}{c}\text { Field B - } \\
\text { Abandoned }\end{array}$ & 0.24 & $\begin{array}{c}\text { Moderate to densely wooded } \\
\text { area. }\end{array}$ & $\begin{array}{l}\text { Intensive } \\
\text { Pedestrian }\end{array}$ & 19 & $\begin{array}{l}\text { 41HR1236, } \\
\text { Isolate 1 }\end{array}$ & $A X$ \\
\hline GR03 & Field C & 1.23 & $\begin{array}{l}\text { Largely disturbed and modified } \\
\text { area containing several existing } \\
\text { pipeline corridors, road right- } \\
\text { of-way, and private drive to a } \\
\text { commercial facility. The field } \\
\text { ends at US Highway } 90 \text {. }\end{array}$ & $\begin{array}{c}\text { Pedestrian } \\
\text { Reconnaissance / } \\
\text { Intensive } \\
\text { Pedestrian }\end{array}$ & 8 & None & $A X$ \\
\hline GR02 & Field D & 1.15 & $\begin{array}{l}\text { Includes a portion under US } 90 \\
\text { right-of-way. Largely disturbed } \\
\text { and modified area containing } \\
\text { road right-of-way and } \\
\text { residential properties. The field } \\
\text { ends at the former Texaco } \\
\text { Country Club Golf Course. }\end{array}$ & $\begin{array}{c}\text { Pedestrian } \\
\text { Reconnaissance / } \\
\text { Intensive } \\
\text { Pedestrian }\end{array}$ & 4 & None & $A X$ \\
\hline GR02 & Golf Coarse & 0.77 & $\begin{array}{l}\text { Approximately } 0.5 \text { miles of the } \\
\text { length is located within the } \\
\text { former golf course with much } \\
\text { of that length overlapping or } \\
\text { located adjacent to existing or } \\
\text { former cart paths. The } \\
\text { remaining length is located in } \\
\text { moderate to dense woods and } \\
\text { Strickland Park. Wooded areas } \\
\text { appear to have been used as a } \\
\text { dumping ground from the } \\
\text { adjacent residential area. }\end{array}$ & $\begin{array}{c}\text { Pedestrian } \\
\text { Reconnaissance / } \\
\text { Intensive } \\
\text { Pedestrian }\end{array}$ & 14 & None & $A X$ \\
\hline \multicolumn{2}{|c|}{ Total Miles } & 7.06 & & Total Tests & 131 & & \\
\hline
\end{tabular}

Table 5-4. Newly identified resources. 


\begin{tabular}{|l|c|l|}
\hline Field Number & Trinomial & \multicolumn{1}{c|}{ Description } \\
\hline Temp Site 1 & $41 \mathrm{HR} 1234$ & $\begin{array}{l}\text { Mid-Twentieth Century historic midden/dump of 200+ bottle glass and jars, few } \\
\text { ceramics, one steak bone. }\end{array}$ \\
\hline Temp Site 2 & $41 \mathrm{HR} 1235$ & $\begin{array}{l}\text { Late Prehistoric ephemeral campsite of a small scatter of local chert and silicified wood } \\
\text { debitage, plain and decorated sandy paste pottery, charred wood and bone and fire- } \\
\text { cracked rock. }\end{array}$ \\
\hline Temp Site 3 & $41 \mathrm{HR} 1236$ & $\begin{array}{l}\text { Multicomponent Late Prehistoric campsite/Historic ceramic isolate of a small scatter of } \\
\text { lithic debitage, sandy paste pottery, a retouched arrow point, and one historic } \\
\text { transferware ceramic sherd. }\end{array}$ \\
\hline Isolate 1 & & One piece of blue-painted ceramic and one plain white ceramic. \\
\hline
\end{tabular}

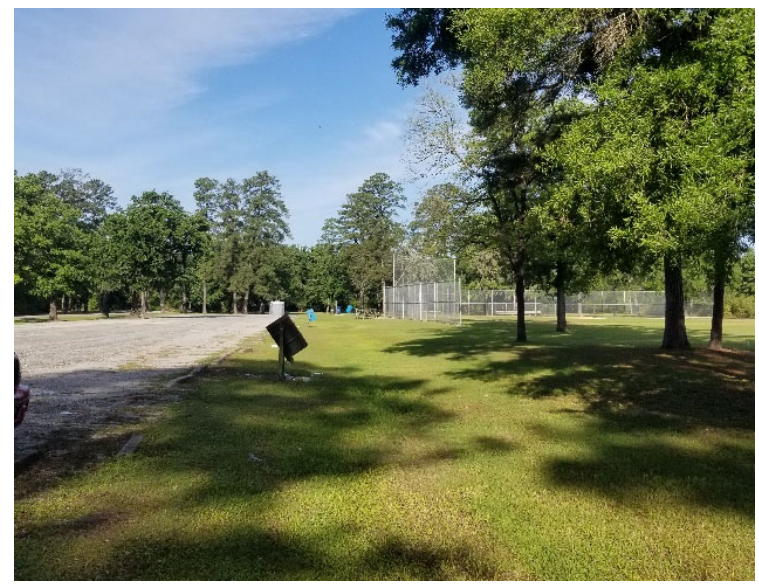

Figure 5-3. Portion of proposed trail located in Brock Park. View is to the west.

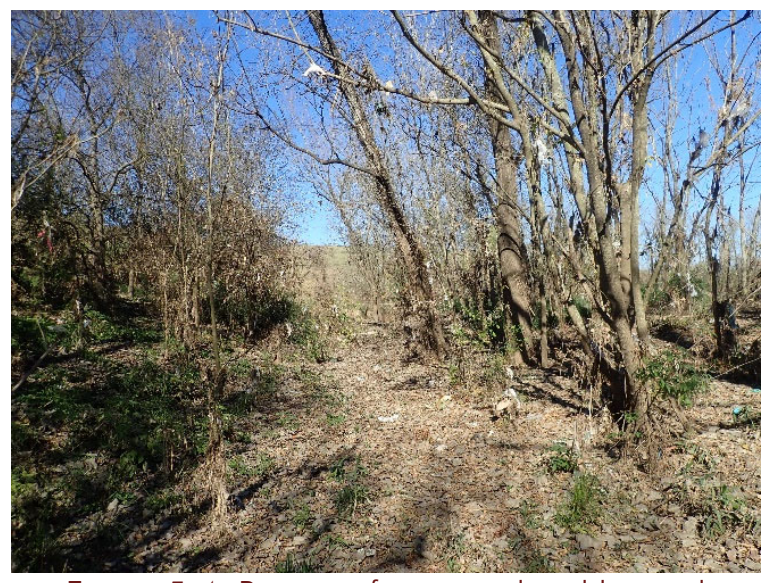

Figure 5-4. Portion of proposed trail located adjacent to a landfill. Note the amount of refuse in the trees indicating previous flood levels. View is to the north.

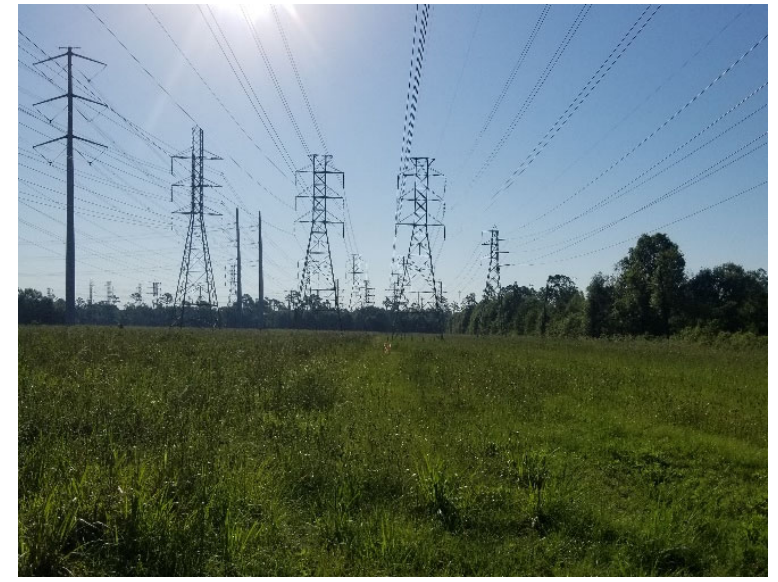

Figure 5-5. Portion of proposed trail located within an existing pipeline and transmission corridor. View is to the east.

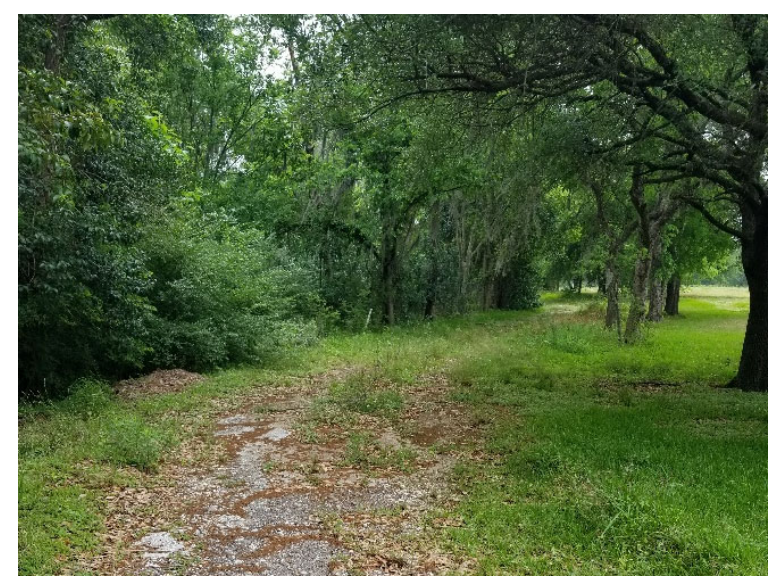

Figure 5-6. Portion of proposed trail located along a former cart path within the former Texaco Country Club golf course. View is to the east. 
REMOVED FROM PUBLIC COPY

Plan view of Site 41HR1234. 


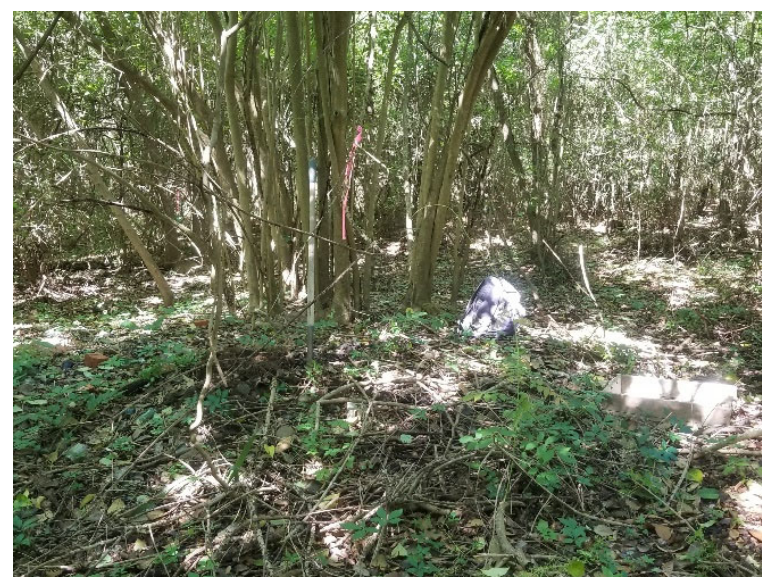

Figure 5-8. Burn pile of predominantly glass bottles observed within Site 41HR1234. View is to the east.

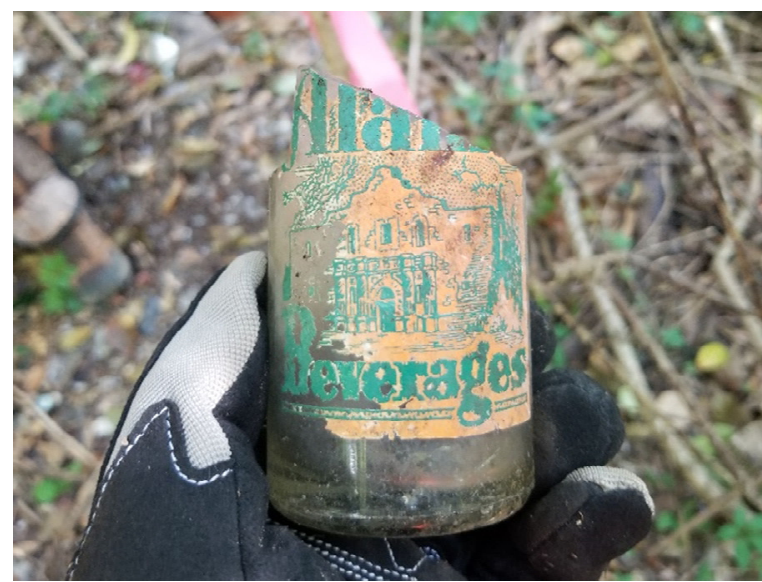

Figure 5-9. Alamo Beverage bottle fragment from Site $41 \mathrm{HR} 1234$.

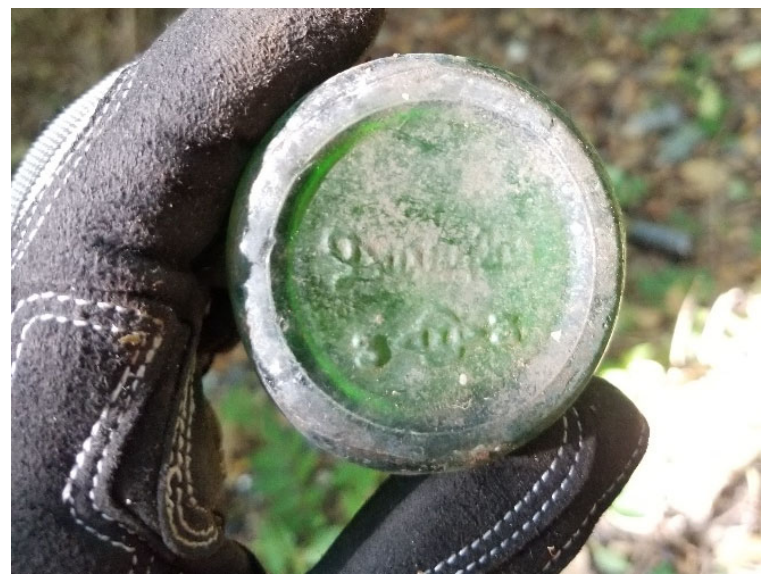

Figure 5-10. Duraglas bottle base observed at Site $41 \mathrm{HR} 1234$.

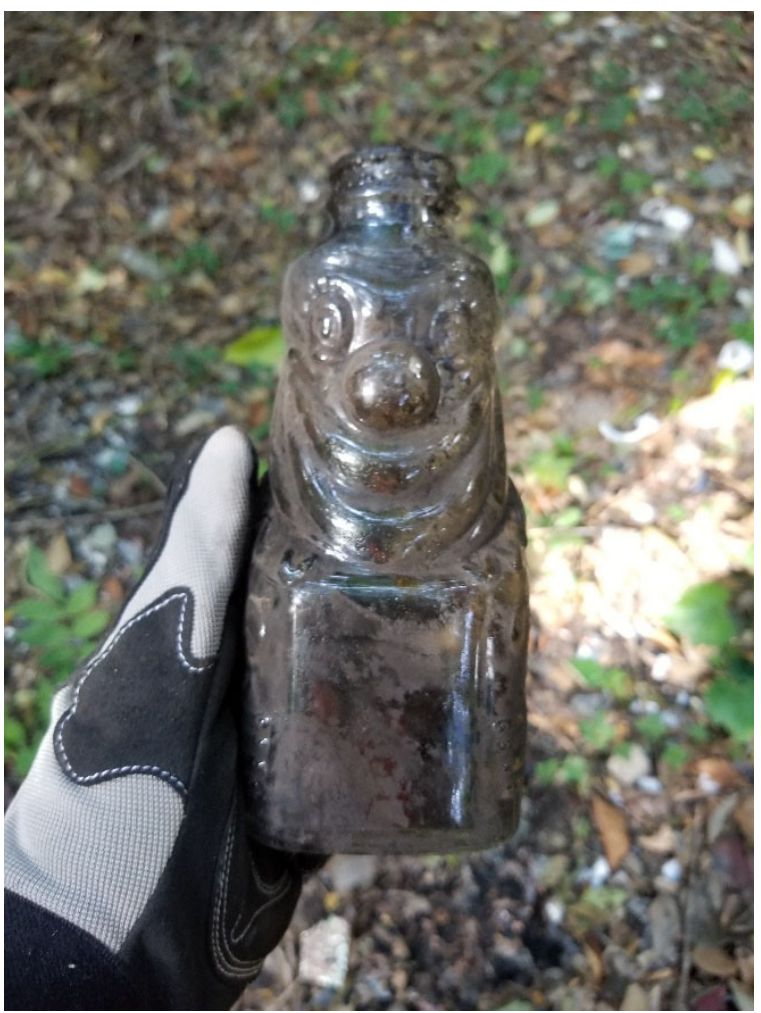

Figure 5-11. A "Grapette Products Co" bottle in the shape of a clown observed at Site 41HR1234.

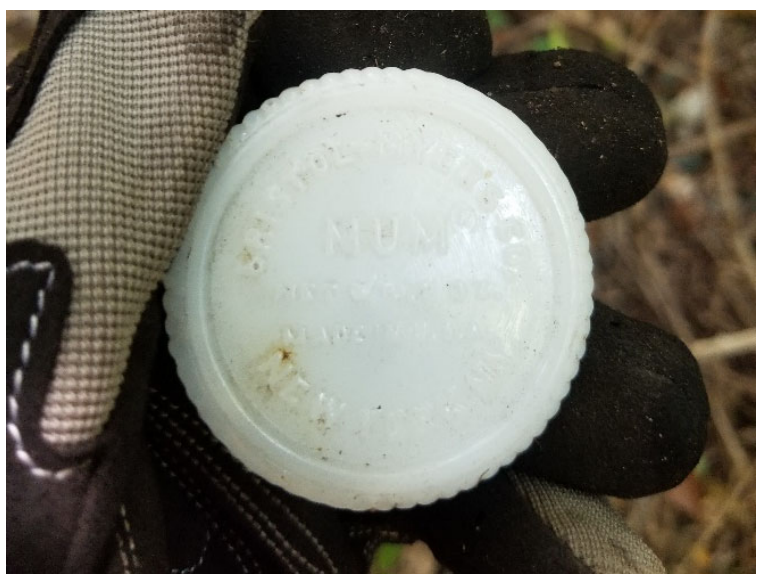

Figure 5-12. Milk glass "MUM" deodorant jar observed at Site 41HR1234.

\subsubsection{Newly Recorded Site 41HR1235}

Site 41HR1235 consists of a Late Prehistoric ephemeral campsite. The site was identified on April 10 and subjected to additional investigation on May 14, 2018. The site is located at the northern portion of Segment GR03/Field A (Figure 5-1 and 5-13). The site is 
REMOVED FROM PUBLIC COPY

Plan view of Site 41HR1235. 
fairly condensed, located at the edge of the floodplain and small landform on a terrace of Halls Bayou. The vegetation is predominately dense riparian woodland (Figure 5-14).

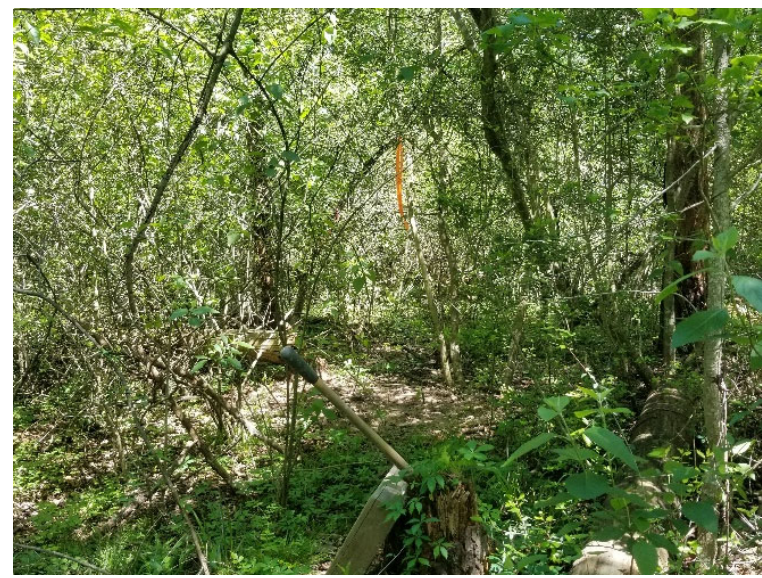

Figure 5-14. Overview of Site 41HR1235. View is to the northeast.

The ground surface is relatively flat east to west and gently sloping north towards the bayou. The site measures approximately 15 meters (49.21 feet) north-south and 20 meters (65.62 feet) east-west. The site was identified by positive Shovel Test A12 which contained several fragments of pottery and lithic debitage as well as charred material and one fire-cracked rock (FCR). An additional 11 delineation shovel tests placed around Test $A 12$ at 5 to 10 -meter (16 to 33-foot) intervals produced another three positive tests (Table 5-5). Observed cultural material includes six pieces of flake stone debitage (4 chert, 2 silicified wood), one firecracked rock (FCR), two charred bone fragments, three charred wood fragments, and 16 fragments of sandy paste ceramic sherds generally measuring 1 centimeter (0.4-inch) wide or less, one of which is a punctated rimsherd (Figure 5-15). Considering cortex and completeness, the lithic artifacts included three complete secondary flakes, one broken secondary flake and two complete interior flakes. Based on the artifact assemblage, it appears that late-stage lithic reduction, cooking, and food processing occurred at the site. The ceramics at the site suggest a Late Prehistoric age.

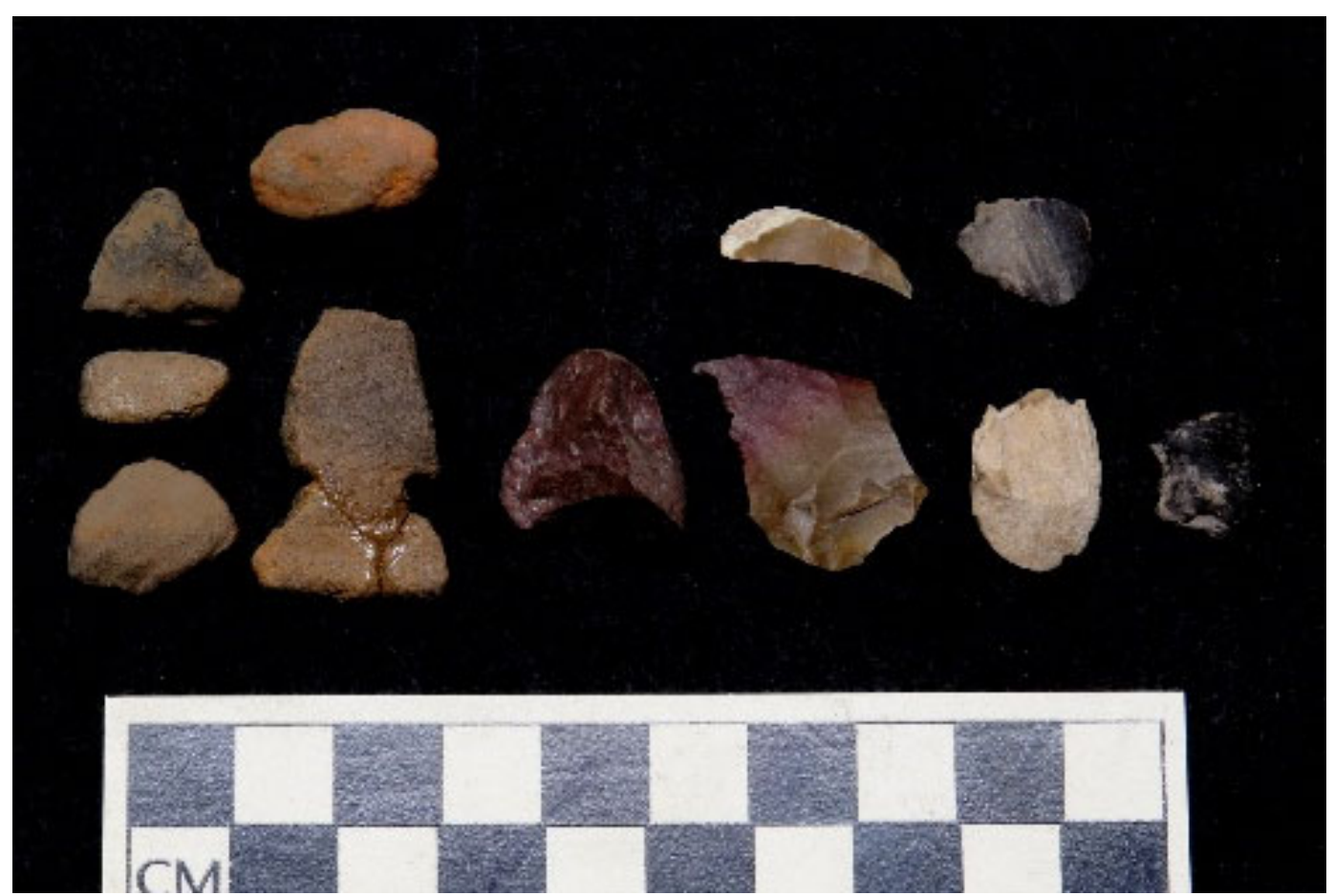

Figure 5-15. Representative artifacts observed at Site 41HR1235, including from left to right: ceramics, FCR, chert debitage, petrified wood debitage, and burned bone. 
The site appears to have been truncated to the north by fluvial erosion but is elsewhere mostly intact and buried within the first stratum of dark grey (10YR 6/2) sandy loam (Appendix B). No artifacts or features were discovered in the lower strata.

Table 5-5. Provenience of Subsurface Materials Identified within Site 41HR1235.

\begin{tabular}{|c|c|c|}
\hline $\begin{array}{l}\text { Test } \\
\text { Number }\end{array}$ & Material & Depth \\
\hline \multirow{4}{*}{$\mathrm{A} 12$} & 1 flakes, 3 pottery & $0-10 \mathrm{~cm}$ \\
\hline & $\begin{array}{c}2 \text { flakes, } 1 \text { FCR, } 4 \\
\text { pottery }\end{array}$ & $\begin{array}{c}10-20 \\
\mathrm{~cm}\end{array}$ \\
\hline & 1 flake, 3 pottery & $\begin{array}{c}20-30 \\
\mathrm{~cm}\end{array}$ \\
\hline & 5 pottery & $\begin{array}{c}30-40 \\
\mathrm{~cm}\end{array}$ \\
\hline $\mathrm{A} 12+10 \mathrm{E}$ & 1 flake & $40 \mathrm{~cm}$ \\
\hline $\mathrm{A} 12+5 \mathrm{~S}$ & 1 flake & $43 \mathrm{~cm}$ \\
\hline $\mathrm{A} 12+5 \mathrm{E}$ & 1 pottery & $\begin{array}{l}10-40 \\
\mathrm{~cm}\end{array}$ \\
\hline
\end{tabular}

Due to the presence of diagnostic materials and a potential thermal feature the site is considered to be potentially eligible and have moderately high research value. The proposed project alignment was subsequently rerouted approximately 67 meters (220 feet) south of the site to avoid the location. Six shovel tests placed along the rerouted alignment produced no additional cultural materials. There will be no direct impacts to the site by the project as currently planned and Gray \& Pape believes the site is sufficiently avoided and protected from indirect effects such as looting due to the distance from the revised project alignment and heavy vegetation surrounding the site.

\subsubsection{Newly Recorded Site 41HR1236}

Site $41 \mathrm{HR} 1236$ consists of a multi-component prehistoric campsite and historic isolate. The site is located at the northern portion of Segment GR03/Field A (Figure 5- 1 and Figures 5-16 through 5-19). The site was identified on
April 11 and subjected to additional investigation on May 14, 2018. The vegetation at the location is predominately dense riparian woodland (Figure 5-16) and the ground surface is gently sloping north towards the bayou and quickly sloping west towards the ravine. The site is fairly condensed, measuring approximately 30 meters (98.43 feet) north-south and 15 meters (49.21 feet) east-west, and is located on a small landform on a narrow terrace that spans between two steep ravines of inlets that feed into Greens Bayou (Figure 5-17).

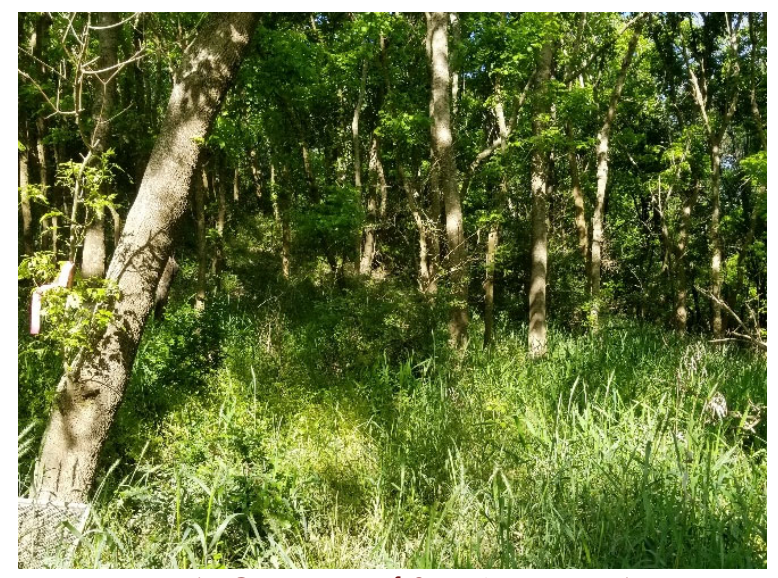

Figure 5-16. Overview of Site 41HR1236. View is to the southwest.

The landform continues for another 45 meters to the east but tests through this area only produced one additional artifact, Isolate 1, which is further discussed in its own subsection below. The site was identified by Shovel Test B9 with an additional six shovel tests placed around it at 5 to 10-meter (16 to 33-foot) intervals. This produced an additional two positive tests (Table 5-6). Observed cultural material includes one broken Perdiz arrow point, two pieces of quartzite debitage, one piece of silicified wood debitage, two sandy paste ceramic sherds, and one historic ceramic (Figures 5-18 to 5-20). In addition to artifacts, a layer of ashy soils was encountered in Test B9 between a depth of 24 and 40 centimeters ( 9 and 16 inches)(Figure 521). 
REMOVED FROM PUBLIC COPY

Plan view of Site 41HR1236 and Isolate 1. 


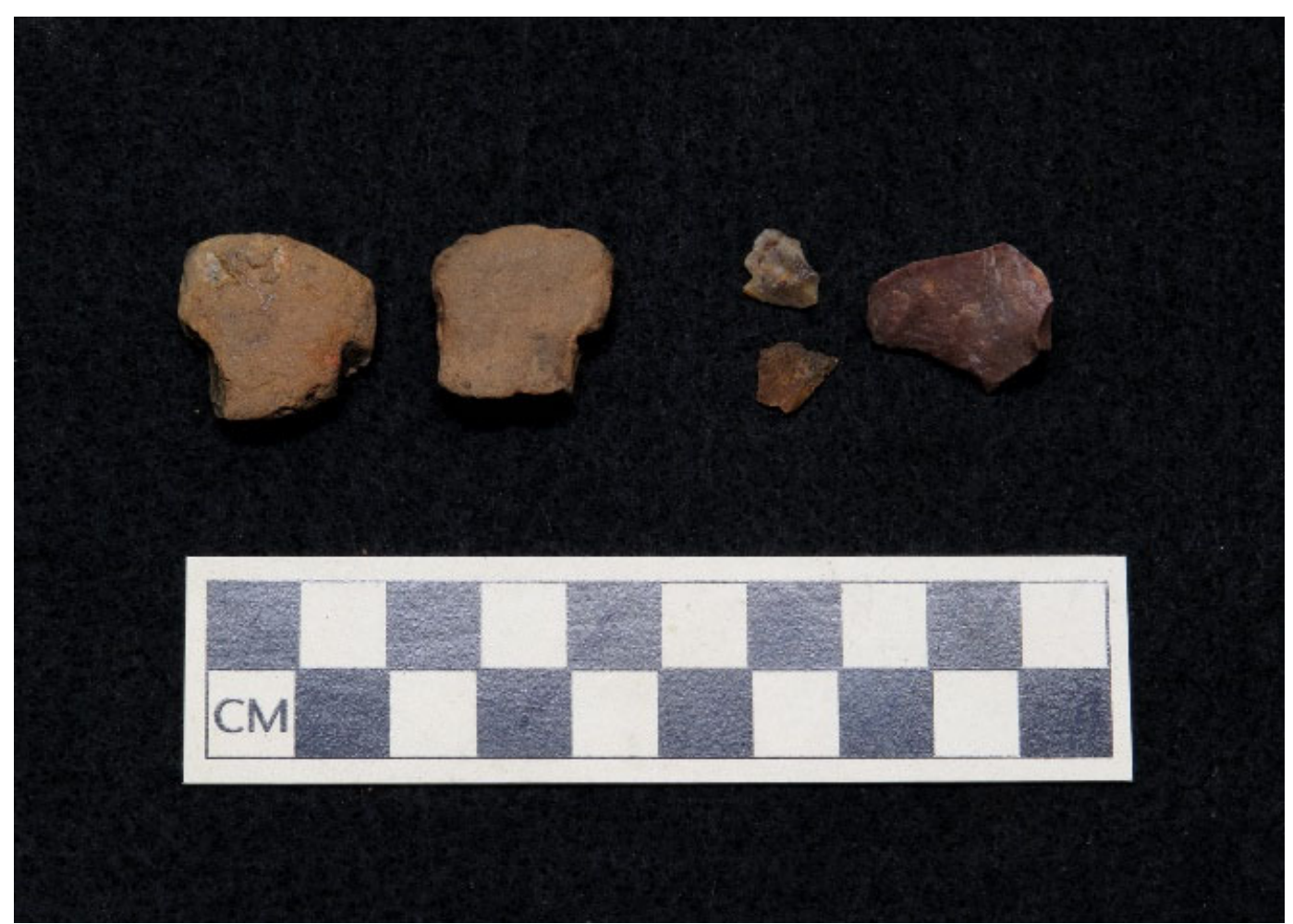

Figure 5-18. Representative prehistoric materials observed at Site 41HR1236.
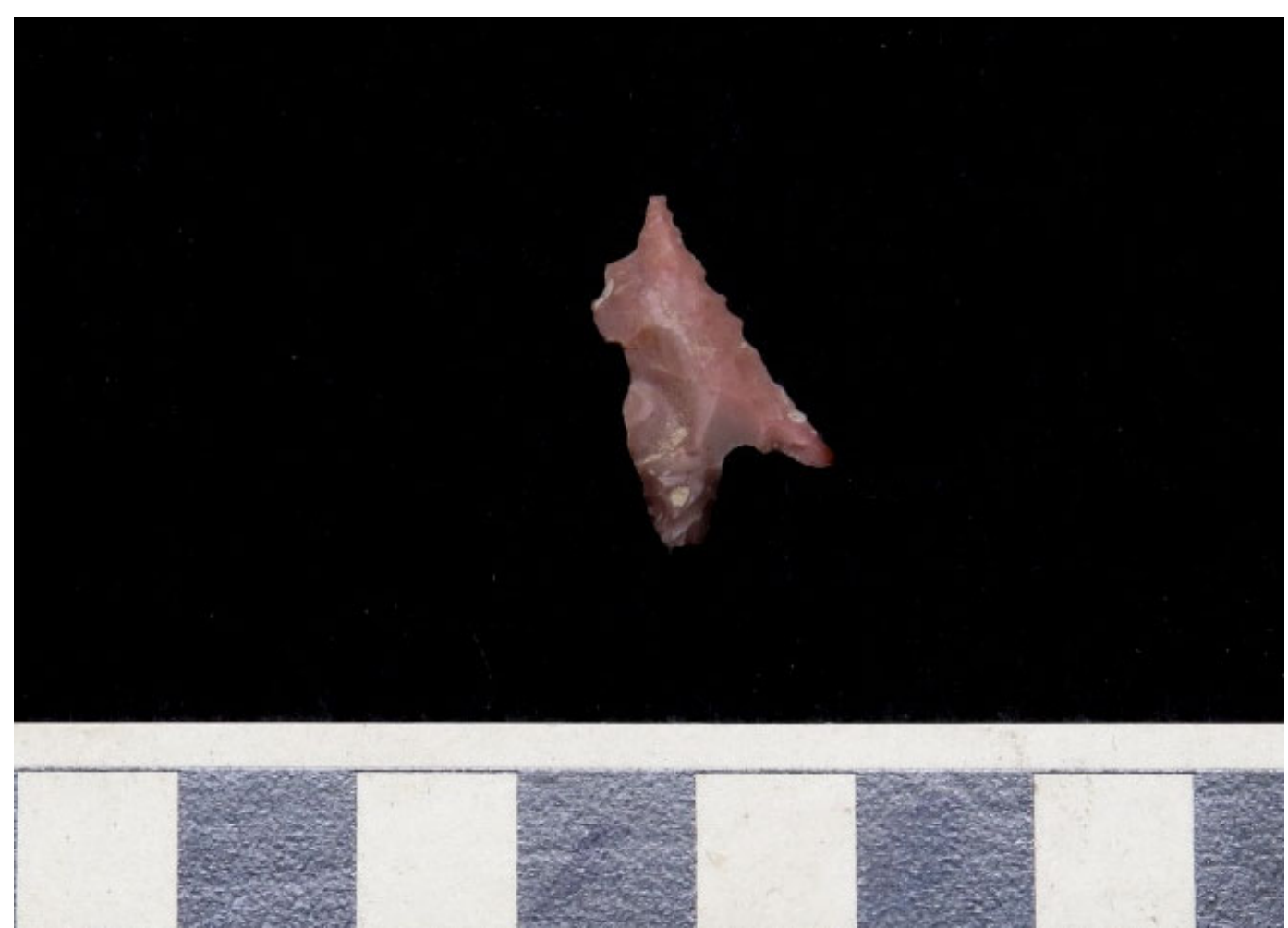

Figure 5-19. Broken Perdiz arrow point observed at Site 41HR1236. 

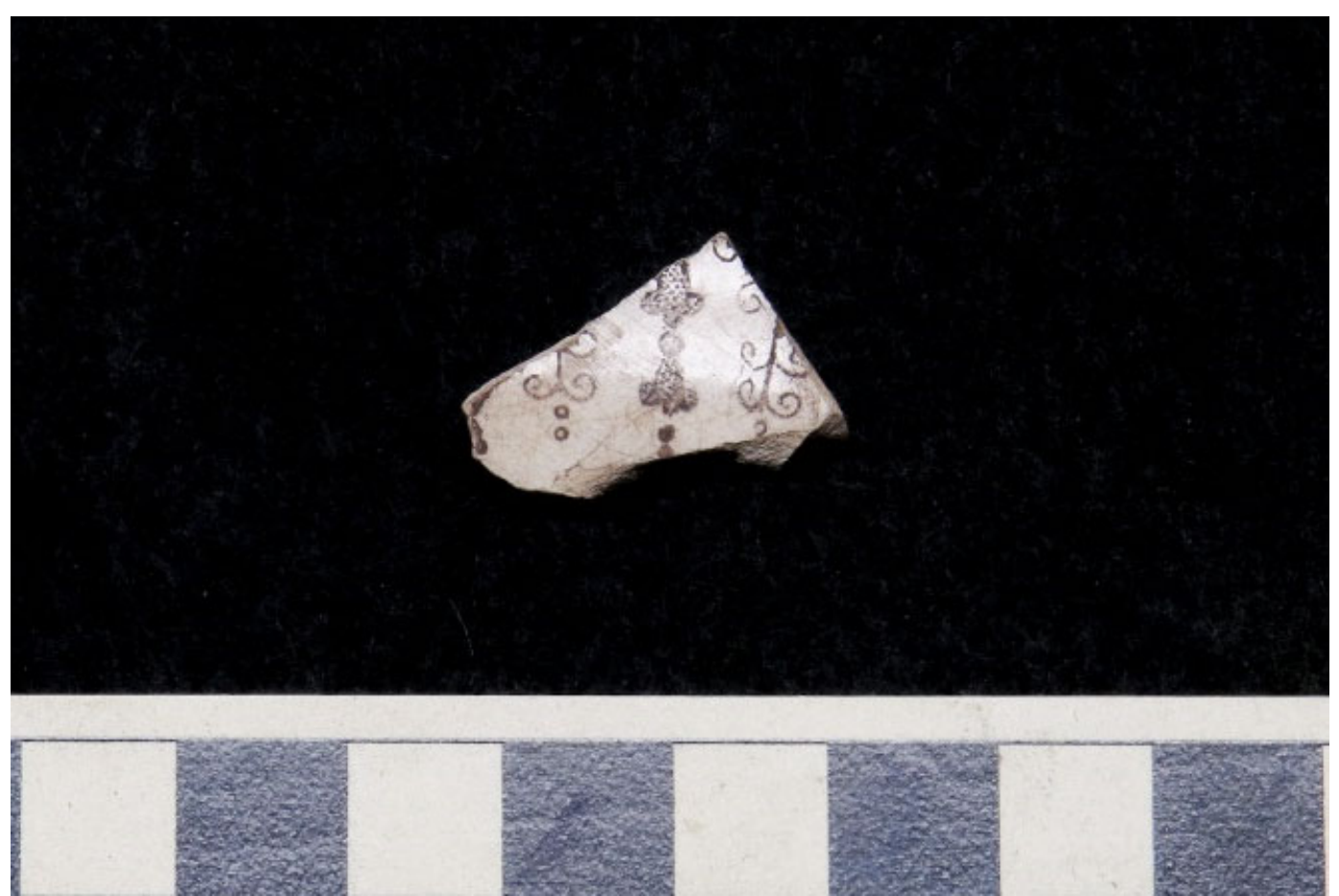

Figure 5-20. Black mulberry transferprint ceramic observed at Site 41HR1236.

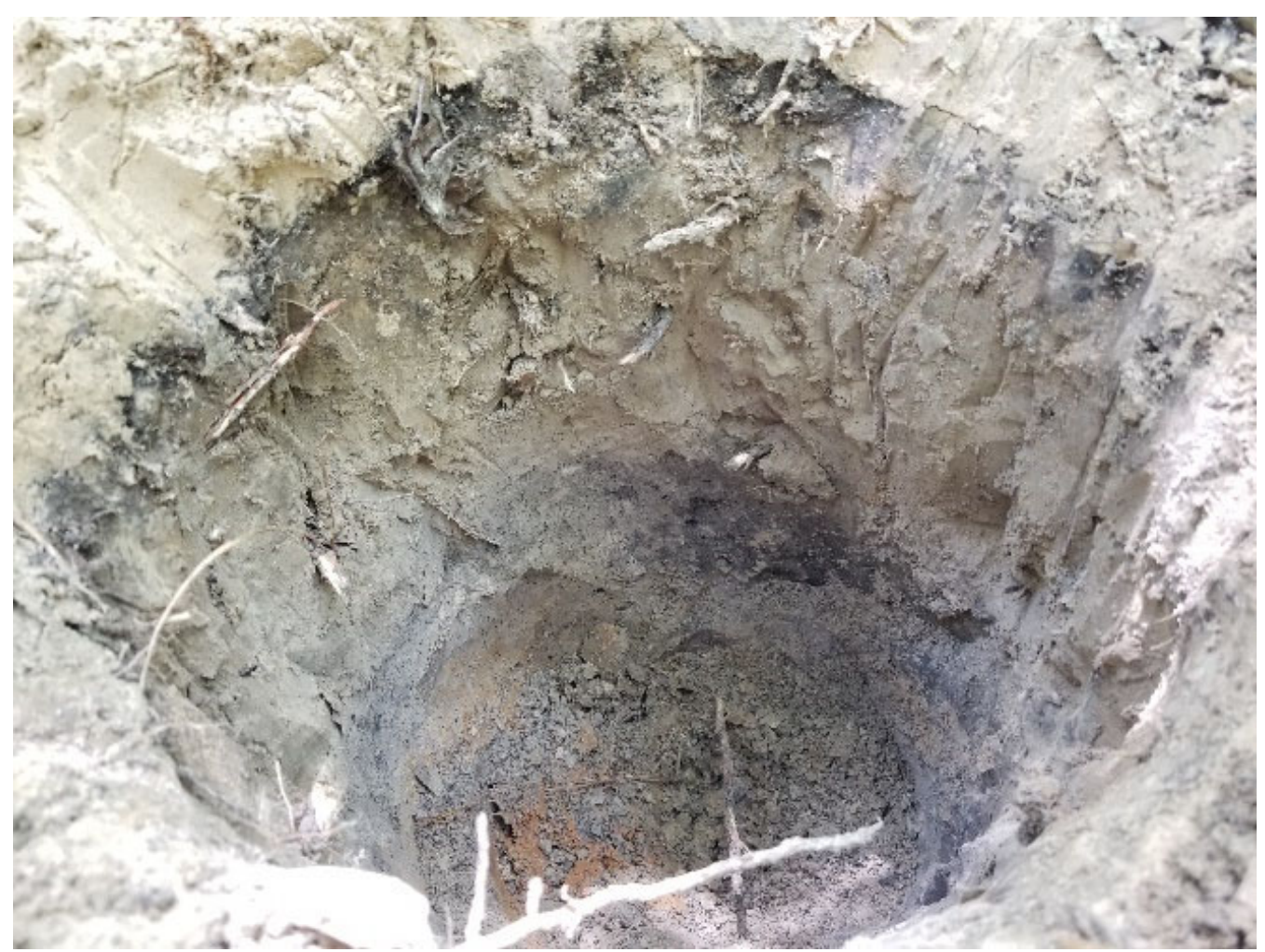

Figure 5-21. Burn layer observed in Shovel Test B9. 
Table 5-6. Provenience of Subsurface Materials Identified within Site 41HR1236.

\begin{tabular}{|c|c|c|}
\hline Test Number & Material & Depth \\
\hline \multirow{2}{*}{ B9 } & 1 historic pottery & $25 \mathrm{~cm}$ \\
\cline { 2 - 3 } & ashy soil layer & $24-40 \mathrm{~cm}$ \\
\hline \multirow{2}{*}{ B9+20S } & 1 Perdiz point & $5-35 \mathrm{~cm}$ \\
\hline \multirow{3}{*}{ B9+5S } & 1 flake & $25-30 \mathrm{~cm}$ \\
\cline { 2 - 3 } & 1 flake, 2 pottery & $30-45 \mathrm{~cm}$ \\
\cline { 2 - 3 } & 1 flake & $45-50 \mathrm{~cm}$ \\
\hline
\end{tabular}

While containing both historic and prehistoric artifacts, the site appears to be more prehistoric in nature. The lone historic artifact consists of a transferprint (mulberry underglaze) on whiteware. Dating for transferprints begin in the early 19th century and continue to the present; however, black/mulberry examples such as this are generally early in the date range (Aultman et al. 2003). Thus, it is safe to date this artifact as 19th century and likely mid-19th century. The historic and prehistoric components of the site are buried in discrete and separate stratigraphic sequences. The site may have been truncated by fluvial erosion from nearby channels.

Due to the presence of diagnostic materials and a potential thermal feature the site is considered to be potentially eligible and have moderately high research value. The proposed project alignment was subsequently rerouted approximately 74 meters (243 feet) south of the site to avoid the location. Fourteen shovel tests placed along the rerouted alignment produced no additional cultural materials. There will be no direct impacts to the site by the project as currently planned and Gray \& Pape believes the site is sufficiently avoided and protected from indirect effects such as looting due to the distance from the revised project alignment and heavy vegetation surrounding the site. A historic-age isolate, Isolate 1 discussed below, identified nearby is potentially related to the site but do due the alluvial nature of the location it is difficult to associate the two with any certainty.

\subsubsection{Isolate 1}

One piece of blue-painted ceramic (Figure 522) and one plain white ceramic fragmented were discovered in Shovel Test B10, located just 25 meters (82 feet) east of Site 41HR1236 (Figure 5-19). The profile for Shovel Test B 10 consisted of a surface layer of 10YR 6/4 flood deposit fine sand to a depth of 5 centimeters (1.97 inches), followed by a layer of 10YR 4/2 sandy loam to a depth of 20 centimeters (7.87 inches) which contained the two cultural artifacts. This was followed by a layer of 10YR $6 / 4$ fine sandy loam to a depth of 50 centimeters (19.69 inches) underlain by 10YR $5 / 6$ silty clay loam. Six delineation tests placed at 10-meter (33-foot) intervals around Test B 10 produced no additional cultural materials. As a result of trail realignment to avoid Site 41HR1236, the location of Isolate 1 will likewise be avoided. No additional work is recommended for the find.

\subsubsection{Additional Non-Archaeological Cultural Finds}

Three areas along the planned alignment contained materials or contexts that are not of a historic nature or in primary context. The locations for these are indicated on Figures 5-1 and 5-2 and Appendix B as Other/Modern. The finds are not considered significant and no further work is recommended for them in regard to the project. The finds are discussed below.

An additional two shovel tests ( $\mathrm{B} 6$ and $\mathrm{A} 7$ ) were positive for modern cultural materials. These are located adjacent to a modified natural gully located just outside of Brock Park to the south within the northern portion of Segment GR03/Field A. The gully contains numerous industrial materials including tires and roofing shingles (Figure 5-23), as well as smaller plastics, glass, and metal. It is apparent that locals have used the proximity of Brock Park to dispose of materials into the woods which have been migrating up and down the gully during periods of heavy rains and floods. 


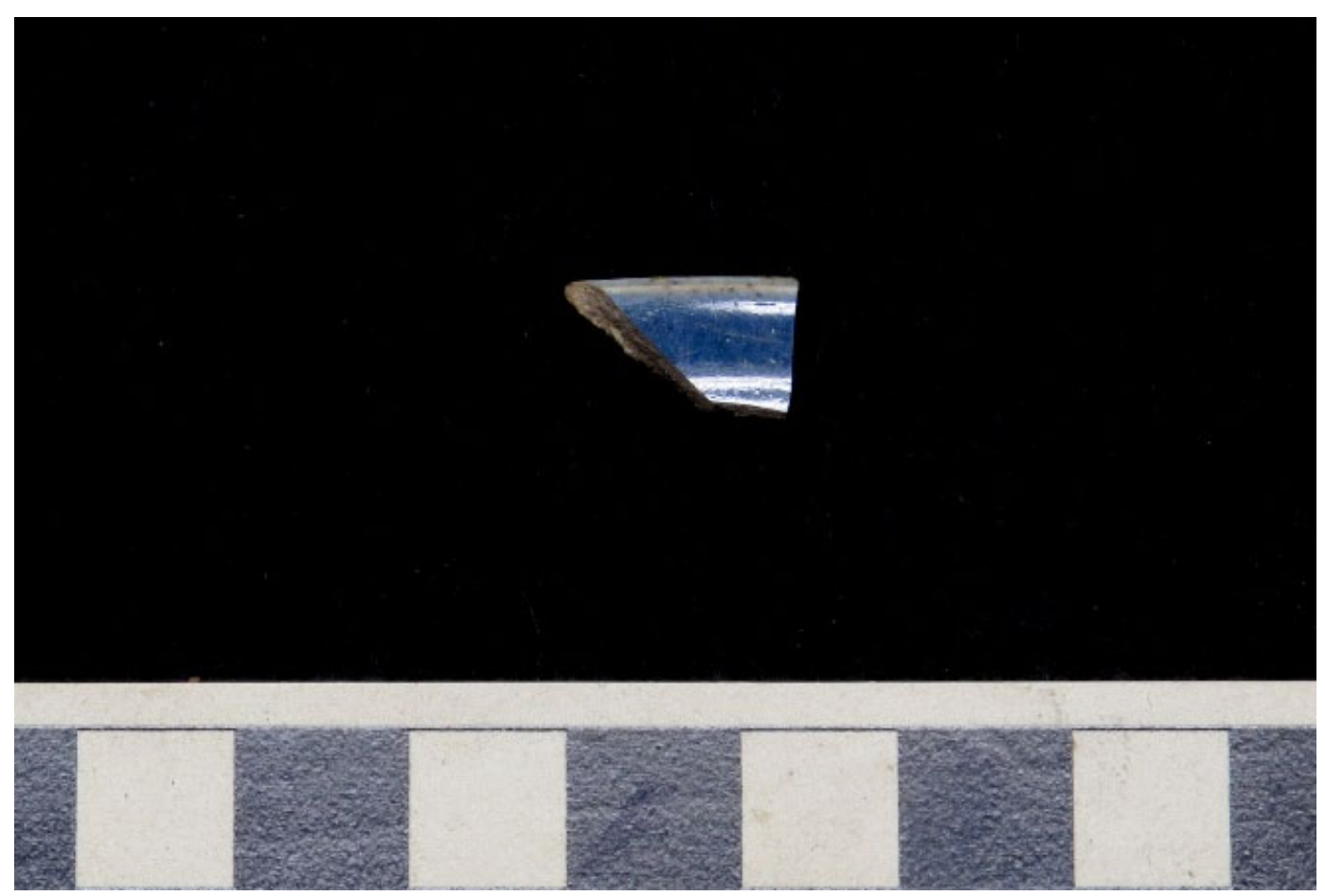

Figure 5-22. Blue painted ceramic comprising Isolate 1.

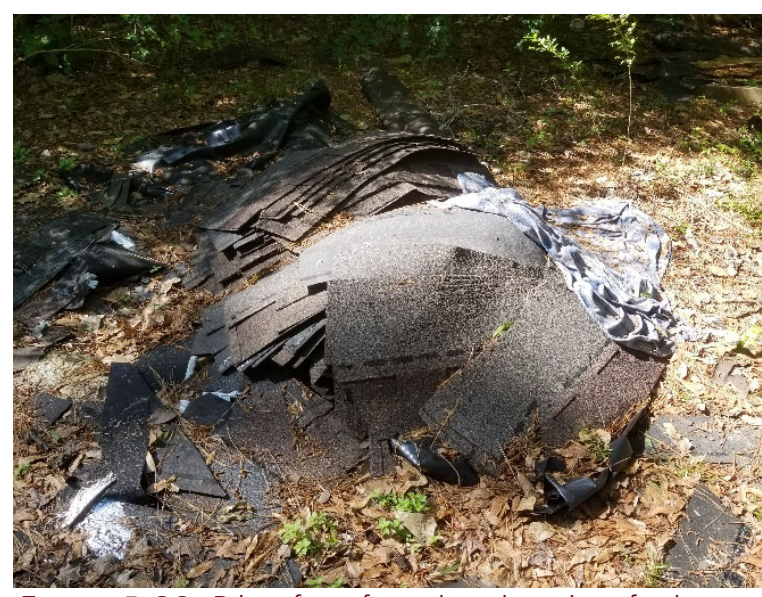

Figure 5-23. Pile of roofing shingles identified near a modified natural gully just south of Brock Park in Trail Segment GR03/Field A. View is to the south.

The portions of project centerline located adjacent to residential areas off Green Dolphin Street (Segment GR02/Field D) and Strickland Park (Segment GR02/Golf Course) both contained concrete/cement rubble piles (Figure 5-24). These areas appeared to be the bulldozed remnants of flood damaged housing slabs or road remnants located in the adjacent neighborhoods.

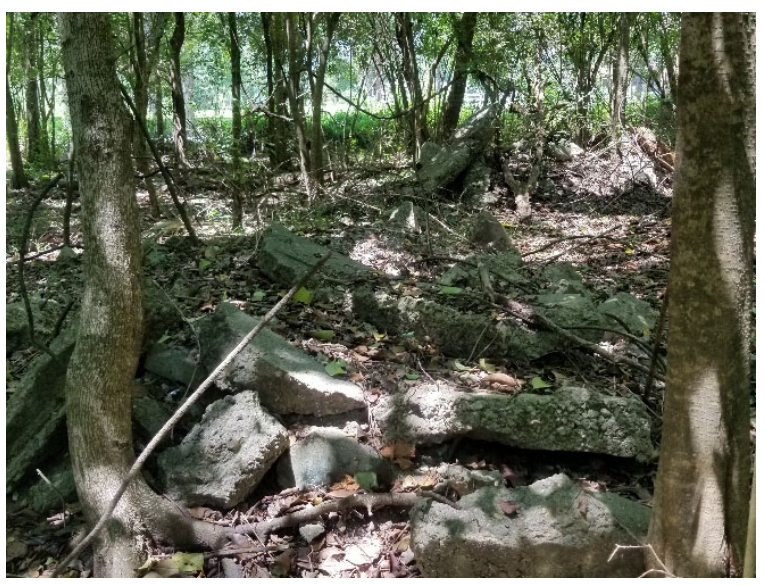

Figure 5-24. Rubble pile of cement slab located near a trail adjacent to Green Dolphin Street, Trail Segment GR02/Field D. View is to the west. 


\subsection{CONCLUSIONS AND RECOMMENDATIONS}

This report summarizes the results of a cultural resources survey of two linear segments (GR02 and GR03), proposed for the construction of a pedestrian trail, in the City of Houston, Harris County, Texas. The project alignment measures approximately 10.8 kilometers $(6.7$ miles $)$ in length and encompasses approximately 9.6 hectares $(23.7$ acres $)$ of area. Another 0.6 kilometers (0.4 miles) or 0.6 hectares (1.4 acres) of project alignment was removed from consideration. In total, approximately 11.4 kilometers (7.1 miles) or 10.2 hectares (25.1 acres) was surveyed for the project. Fieldwork was carried out under TACP 8328.

The goals of the survey were to determine if the proposed development would affect any previously identified historic properties and to establish whether or not previously unidentified cultural resources were located within the APE. Prior to fieldwork mobilization, a background literature and site file search was conducted to identify the presence of recorded sites and previous cultural resource surveys within or near the APE. Thirteen surveys and five archaeological sites have been previously recorded within a 1.6-kilometer (1-mile) study radius of the APE. No previously recorded cultural sites overlap with the current project APE.
Fieldwork was conducted over several mobilizations between April 2018 and January 2020. A total of 131 shovel tests were excavated across the length of current and former alignments of the project, eleven of which were positive for cultural material. All remaining shovel tests were negative for cultural resources. Three archaeological sites and one Historic Isolate were identified as a result of survey (Table 6-1).

Site 41HR1234 was identified as a midtwentieth century historic trash midden. Due to the burned and fragmentary and recent nature of the materials, the site is recommended as ineligible for listing on the NRHP or as a SAL and not recommended for further investigation in regard to the current project.

Site 41HR1235 was identified as a Late Prehistoric ephemeral campsite as evidenced by the presence of sandy paste and punctated pottery. The site is considered to be potentially eligible based on the presence of diagnostic ceramic artifacts and the potential for a thermal feature and likely contains moderately high research value.

Table 6-1. Summary of recommendations for resources identified within the APE.

\begin{tabular}{|c|l|c|c|c|}
\hline Trinomial & \multicolumn{1}{|c|}{ Description } & \multicolumn{1}{|c|}{$\begin{array}{c}\text { Eligibility } \\
\text { Recommendation }\end{array}$} & $\begin{array}{c}\text { Project Status } \\
\text { Recommendations }\end{array}$ \\
\hline $41 \mathrm{HR} 1234$ & $\begin{array}{l}\text { Mid-twentieth century } \\
\text { historic trash dump }\end{array}$ & Ineligible & $\begin{array}{c}\text { Planned for } \\
\text { Impact }\end{array}$ & No Further Work \\
\hline $41 \mathrm{HR} 1235$ & $\begin{array}{l}\text { Late Prehistoric ephemeral } \\
\text { campsite }\end{array}$ & Potentially Eligible & $\begin{array}{l}\text { No Further Work, } \\
\text { Eligibility Testing if } \\
\text { Potentially Impacted } \\
\text { by Future Projects }\end{array}$ \\
\hline $41 \mathrm{HR} 1236$ & $\begin{array}{l}\text { Multicomponent Late } \\
\text { Prehistoric } \\
\text { campsite/Historic ceramic } \\
\text { isolate }\end{array}$ & Potentially Eligible & Avoided & $\begin{array}{l}\text { No Further Work, } \\
\text { Eligibility Testing if } \\
\text { Potentially Impacted } \\
\text { by Future Projects }\end{array}$ \\
\hline Isolate 1 & Two historic ceramics & Ineligible & Avoided & No Further Work \\
\hline
\end{tabular}


Site 41HR1236 was recorded as a multicomponent prehistoric campsite and historic isolate. Diagnostic artifacts at the site consist of a broken Perdiz arrow point and two sandy paste ceramics indicative of a Late Prehistoric time frame. The lone historic artifact consists of a black pattern transferware ceramic fragment. The site also includes a likely thermal feature. The site is considered to be potentially eligible based on the presence of diagnostic ceramic artifacts and the potential for a thermal feature and likely contains moderately high research value.

While diagnostic artifacts were observed at all three sites, it is the recommendation of Gray \& Pape that only Sites 41 HR 1235 and 41 HR 1236 are significant in the materials they contain and their potential to offer additional research potential. Direct impacts to both sites have been avoided by the project alignment as currently planned. While indirect impacts such as looting are a concern, the distance between the sites and the current alignment as well the density of woods surrounding them minimizes the danger as a result of the project. Eligibility testing is recommended for the sites if they cannot be avoided by future projects.

Based on the results of this survey, Gray \& Pape recommends that the no further cultural resources work be required for the project as currently planned and that the project be cleared to proceed. 


\subsection{REFERENCES CITED}

Abbott, James $T$.

2001 Houston Area Geoarcheology: A Framework for Archeological Investigation, Interpretation, and Cultural Resource Management in the Houston Highway District. Texas Department of Transportation, Environmental Affairs Division, Houston.

Aten, Lawrence $\mathrm{E}$.

1983 Indians of the Upper Texas Coast. Academic Press, New York.

1984 Woodland Cultures on the Texas Coast. In Perspective on Gulf Coast History, edited by Dave D. Davis, pp. 72-93. Ripley P. Bullen Monographs in Anthropology and History, No. 5. Florida State Museum, University Press of Florida, Gainesville.

Aultman, Jennifer, Kate Grillo, and Nick Bon-Harper

2003 DAACS Cataloging Manual: Ceramics. Thomas Jefferson Foundation, Charlottesville, Virginia. http://www.daacs.org/aboutDatabase/pdf/cataloging/Ceramics.pdf

Barnes, V.E.

1982 Geologic Atlas of Texas, Houston Sheet, revised. Bureau of Economic Geology, University of Texas at Austin, Austin.

Biesaart, Lynne A., Wayne R. Robertson, and Lisa Springs

1985 Prehistoric Archaeological Sites in Texas: A Statistical Overview. Office of the State Archaeological Report 28. Texas Historical Commission, Austin.

Culberson, Linda C.

1993 Arrowheads and Spear Points in the Prehistoric Southeast: A Guide to Understanding Cultural Artifacts. University Press of Mississippi, Jackson.

Deiss, Ronald W.

1981 The Development and Application of a Chronology for American Glass. Master's thesis, Illinois State University, Normal, IL.

Gregory, H.F.

1986 The Southern Caddo: An Anthology. Garland Publishing: New York.

Google, Inc.

2019 Google Earth. Aerial Imagery 1944, 1953, 1978, 1989, 1995, 2002, 2004-2006, 20082019. Accessed June 7, 2019.

Henson, Margaret

2017 Harris County, TX. The Handbook of Texas Online. http://www.tshaonline.org/handbook/online/articles/hch07. Accessed May 8, 2017.

Holloway, Vance T.

1997 Paleoindian Geoarchaeology of the Southern High Plains. The University of Texas Press, Austin. 
Hudson, Charles

1976 The Southeastern Indians. The University of Tennessee Press, Nashville.

La Vere, David

1998 The Caddo Chiefdoms: Caddo Economics and Politics, 700-1835. The University of Nebraska Press, Lincoln.

Lief, Alfred

1965 A Close-up of Closures: History and Progress. Glass Container Manufactures Institute, New York.

Lindsey, Bill

2018 Historic Glass Bottle Identification \& Information Website. ONLINE. 2010. Society for Historical Archaeology and Bureau of Land Management. Available: http://www.sha.org/bottle/index.htm. Accessed May 2018.

Munsell Soil Color Chart (Munsell)

2005 Revised Edition. Macbeth Division of Kollmorgan Instruments Corporation.

Newcomb, W.W. Jr.

1961 The Indians of Texas From Prehistoric to Modern Times. The University of Texas Press, Austin.

Patterson, Leland

1995 The Archeology of Southeast Texas. Bulletin of the Texas Archeological Society 66:239264.

1996 Southeast Texas Archeology. Report No. 12, Houston Archeological Society

Sanchez, Joseph M., Bob Dagel, Kelly Lackey, and Roger Moore

1994 Site 41HR751. Archeological Site Form (Atlas Number 9201075101). Texas Historical Commission Site Atlas. https://atlas.thc.state.tx.us/. Accessed June 2019.

Shafer, Harry J.

1975 Comments on the Woodland Cultures of Texas. Bulletin of the Texas Archeological Society 46:249-254.

Sjoberg, A.A.

1951 The Bidai Indians of Southeastern Texas. Southwestern Journal of Anthropology 7(4).

Soil Survey Staff, Natural Resources Conservation Service, United States Department of Agriculture (SSS NRCS USDA)

2019 Web Soil Survey. http://websoilsurvey.nrcs.usda.gov/app/WebSoilSurvey.aspx. Accessed June 7, 2019.

Story, Dee Ann

1990 Cultural History of the Native Americans. In The Archeology and Bioarcheology of the Gulf Coastal Plain 1: 163-366. 2 vols. Research Series No. 38. Fayetteville, Arkansas Archeological Survey. 
Toulouse, Julian Harrison

1971 Bottle Makers and Their Marks. New York: Thomas Nelson, Inc. 1971.

Turner, E.S. and T.R. Hester

1993 A Field Guide to Stone Artifacts of Texas Indians, 2nd Edition. Texas Monthly Field Guide Series. Gulf Publishing Co., Houston.

United States Geological Survey (USGS)

1982 Jacinto City, Texas Quadrangle (7.5 minute). USGS.

University of Texas, Bureau of Economic Geology (UT-BEG)

1997 Physiographic Map of Texas. Map reproduced by the United States Geological Survey (USGS), 1997.

2010 Ecoregions of Texas. Map reproduced by the United States Geological Survey (USGS), 2004.

Van Siclen, D.C.

1991 Surficial Geology of the Houston Area: An Off-lapping Series of Pleistocene (\& Pliocene?) Highest Sea Level Fluviodeltaic Sequences. In Transactions of the Gulf Coast Association of Geological Societies, Volume 41:651-666.

Wheeler, F.F.

1976 Soil Survey of Harris County, Texas. United States Department of Agriculture, Soil Conservation Service, Washington D.C. 


\section{APPENDIX A: PROJECT RESULTS}

\section{REMOVED FROM PUBLIC COPY}


APPENDIX B: SHOVEL TEST LOG

\section{REMOVED FROM PUBLIC COPY}

